\title{
Isolation of Probiotic Lactobacilli Bacteria from Traditional Naein Dairy Product (Koome)
}

\author{
Nina Shemshad ${ }^{1}$, Leila Roozbeh Nasiraie ${ }^{2,3^{*}}$, Reza Majidzadeh Heravi ${ }^{4}$ id
}

1. PhD Student, Department of Science and Food Technology, Nour branch, Islamic Azad University, Nour, Iran

2. Assistant Professor, Department of Science and Food Technology,Nour branch, Islamic Azad University, Nour, Iran

3. Manager of Research and development center, Shams Bavaran Salamat Nour Consulting \& Production Services, Tehran, Iran

4. Assistant Professor, Department of Animal Science, Faculty of Agriculture, Ferdowsi University of Mashhad, Mashhad, Iran

\section{ABSTRACT}

Background and Aim: Koome as one of the traditional fermented dairy products of ovine milk has long been produced in rural areas around Naein, Iran in sheepskin bags. The present study aimed to isolate Lactobacillus bacteria from the traditional dairy products of Naein and to evaluate the functional characteristics and health of these bacteria as probiotics.

Materials and Methods: For the initial isolation of bacteria, de Man, Rogosa, and Sharpe (MRS) agar was used. A total of 15 bacilliform, gram-positive, and catalase-negative colonies were isolated from the culture, and resistance to acid, bile, gastric juice, and intestinal juice was assessed to investigate probiotic characteristics. Bacterial isolates with favorable probiotic characteristics were tested for antimicrobial activity and antibiotic resistance to assess the effect of probiotics on health. Afterwards, seven bacterial isolates were selected and their ability for reducing cholesterol and hydrolyzing bile salts was evaluated. Moreover, the selected isolates were sequenced to identify the strain.

Results: Our findings demonstrated that six of 15 bacterial isolates had a suitable resistance in $\mathrm{pH}=2.5$. In addition, $60 \%$ of the isolates were sensitive to bile salts. The identified Lactobacillus isolates had a high antibiotic resistance and were shown to have a favorable antimicrobial activity against pathogenic bacteria. Furthermore, the selected bacterial isolate could reduce $70 \%$ of environmental cholesterol.

Conclusion: According to the results of the present study, koome is highly potential for isolating probiotic isolates and the nutritional consumption of Lactobacillus isolates s microbial supplement might have positive effects on health.

Keywords: Diary products, Koome, Lactobacillus, Probiotic

Received: 2020/05/15; Accepted: 2020/11/07; Published Online: 2021/01/10

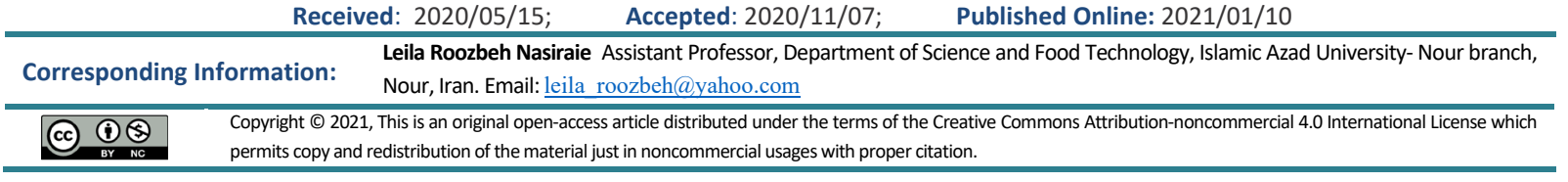

Use your device to scan and read the article online

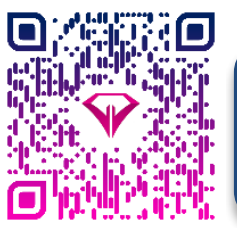

Shemshad N, Roozbeh Nasiraie L, Majidzadeh Heravi R. Isolation of Probiotic Lactobacilli Bacteria from Traditional Naein Dairy Product (Koome). Iran J Med Microbiol. 2021; 15 (1) :85-106

\section{Download citation: BibTeX | RIS | EndNote | Medlars | ProCite | Reference Manager | RefWorks}

\section{Send citation to: $\Theta_{\text {Mendeley }} \mathbf{z}$ zotero $\overline{\mathrm{H}}$ RefWorks}

\section{Introduction}

Fermented products, such as yogurt, kefir, sauerkraut, kombucha, and other dairy products, which have traditionally been used by people since ancient times now entered the field of biotechnology (1). Science of probiotic therapy as the result of the development of this process in food microbiology addresses the beneficial influences of probiotics (live microorganisms in food) in the host body (2). 
Therapeutic effects and the positive impacts of probiotics on health are important due to stimulating the growth of intestinal beneficial microorganisms, decreasing the population of harmful bacteria, and helping the natural defense mechanisms of the body (3). Benefits of the lactic acid bacteria (LAB) isolated from traditional dairy products in preventing and treating diseases have been confirmed and no negative side effects have been noted for these probiotics (4).

Probiotic bacteria of the LAB group are grampositive bacteria present in the microbial flora of the human digestive system. These bacteria are applied in food fermentation procedures and nowadays are considered as a mucosal barrier with the ability for regulating immune responses (5). According to the National Food Standard, probiotic bacteria should survive not only during the shelf life of food but also after passing through gastric acid, enzymes, and bile alkaline salts and should reach their activity site (intestine). Therefore, the foods which are claimed to impose healthy effects need to contain $10^{7}$ living probiotics per one gram at the time of consumption (1).

Lactobacilli were isolated from milk the first time and nowadays in the food industry, probiotics are known as a part of fermented dairy products, including kefir and soured milk. Over 70 products containing $\mathrm{LAB}$ are being produced throughout the world, namely sour cream, powdered milk, and fermented beverages (1). Koome is a traditional dairy product of ovine milk, which has long been produced in sheepskin bags in the rural areas around Naein, Isfahan province, Iran. Considering the unique physicochemical and microbiologic characteristics and the lack of salt, koome could be proposed as one of the best traditional dairy products with long shelf life.

Sharifi et al. (2017) evaluated 96 samples of traditional bovine, ovine, and caprine yogurt. Their results revealed that 47 samples had LAB with probiotic characteristics, including Lactobacillus lactis, L. brevis, and L. fermentum (6). Famouri et al. (2017) investigated the therapeutic characteristics and health effects of $L$. plantarum and L. brevis isolated from ten specimens of traditional fermented dairy products. Reduced serum cholesterol and heavy metals were among the favorable findings (7).

Handa et al. (2016) studied the LAB from two samples of fermented grain-based drinks. They isolated and identified the LAB with probiotic characteristics, such as Lactobacillus fermentum and Lactobacillus acidophilus and confirmed the positive effects of these bacteria on health (2). The present study aimed to isolate Lactobacilli with probiotic potential from the traditional dairy products of Naein,
Iran. This genus of bacteria is widely used in diverse industries, namely the food, pharmaceutical, and supplements industries. Therefore, the recognition and classification of this genius of bacteria provide valuable information for researchers in different fields.

\section{Materials and Methods}

\section{Sampling and Microbial Culture}

A total of five bovine koome samples and three ovine koome specimens were collected from the surrounding rural areas of Naein. Next, for isolation, a homogeny of $10 \mathrm{~g}$ of each sample in $90 \mathrm{~mL}$ of diluent was made and serial dilutions were obtained. The dilutions were inoculated on MRS agar and were incubated at $37^{\circ} \mathrm{C}$ for $24 \mathrm{~h}$. The grown colonies were tested for isolating Lactobacilli from other organisms and morphologic evaluation. To this aim, each colony was cultured on medium to reach a single colony and purify. Afterwards, the purified culture was stored for further tests (8).

\section{Isolating Lactobacilli}

A catalase test was carried out to check the production of catalase enzyme by bacteria. In this test, a small part of the intended colony was placed on a sterile slide using a sterile loop and was mixed with a drop of hydrogen peroxide $3 \%$ (catalase reagent). The lack of bubble production means that the tested bacterium does not produce catalase enzyme and is known as catalase-negative. At the end of this step, the bacilliform, catalase-negative, and gram positive Lactobacilli colonies with different morphologies were coded and assessed for probiotic properties. Superficial culture was performed from the coded samples (9).

\section{Probiotic Evaluation}

\section{Resistance to Bile and Acid Conditions}

Survival of microorganisms was investigated in broth medium with acidic $\mathrm{pH}$ of 2, 2.5, and 3 similar to the digestive system. The number of living microorganisms was counted as presented as a percentage of the initial number following incubation at $37^{\circ} \mathrm{C}$ for 1 and $2 \mathrm{~h}$. Resistance and growth reduction of microorganisms were assessed through incubating at $37^{\circ} \mathrm{C}$ for $8 \mathrm{~h}$ the presence of $0.7 \%$ and $1 \%$ of bile salts (bile oxalate).

The resistance of microorganisms in gastric and intestinal conditions was tested by inoculation to simulated broth media for the stomach $(6.23 \mathrm{~g}$ sodium chloride, $0.229 \mathrm{~g}$ calcium chloride, $2.29 \mathrm{~g}$ potassium chloride, $1.2 \mathrm{~g}$ sodium bicarbonate, pepsin enzyme with the concentration of $0.3 \%$, and $\mathrm{pH}=2 \pm 0.2$ ) and intestine ( $1.28 \mathrm{~g}$ sodium chloride, $0.239 \mathrm{~g}$ potassium chloride, $6.4 \mathrm{~g}$ calcium bicarbonate, $0.5 \% \mathrm{X}$-gal and 
pancreatin enzyme with the final concentration of $0.1 \%$, and $\mathrm{pH}=8$ ). Next, culture was completed on agar medium and colonies were counted following overnight incubation at $37^{\circ} \mathrm{C}(8)$.

\section{Identification of Acid-producing Bacteria}

Acidproductionin culture medium by microorganisms was investigated based on $\mathrm{pH}$ reduction in the medium after $24 \mathrm{~h}$ incubation at $37^{\circ} \mathrm{C}$. Bacteria with a lower $\mathrm{pH}$ than the initial $\mathrm{pH}$ of 6.22 were considered as acidproducing microorganisms (10).

\section{Antimicrobial Activity}

The ability of the intended isolates for producing antimicrobial compounds against standard pathogen bacteria was examined based on the presence of the zone of inhibition on agar medium. In this method, 200 $\mu \mathrm{L}$ of the active culture of pathogen bacterium was inoculated to a tube containing nutrient agar culture medium 1\% (soft agar) and was added to nutrient agar $1.5 \%$ in a plate after cooling and was refrigerated for 30 min. Afterwards, sterile blank discs dipped in the supernatant of the isolate were fixed smoothly on the plate and were refrigerated for $20 \mathrm{~min}$ followed by incubation at $37^{\circ} \mathrm{C}$. After incubation, the zone of inhibition was measured using a ruler and the presence of this zone was reported as antimicrobial impact against pathogen microorganisms (11).

\section{Antibiotic Resistance}

Sensitivity or resistance of probiotic bacteria to common antibiotics in medicine was evaluated by measuring the diameter of the zone of inhibition. First, active culture was prepared from probiotic bacteria. Next, $4 \mathrm{~mL}$ of sterile MRS agar $1 \%$ was poured into each tube. Following the cooling of culture media, 200 $\mu \mathrm{L}$ of fresh active probiotic culture was inoculated to each tube and was mixed thoroughly.

Plates containing MRS agar $1.5 \%$ were prepared and located at room temperature for $10 \mathrm{~min}$ to reach room temperature. Afterwards, a culture medium containing the prepared bacterium was gently added to the plate and refrigerated for $30 \mathrm{~min}$ until the bacteria were absorbed on the medium. Plates were taken out of the refrigerator and sterile antibiotic discs with a diameter of $0.7 \mathrm{~cm}$ were located and the plates were refrigerated for $20 \mathrm{~min}$. Next, plates were incubated at $30^{\circ} \mathrm{C}$ for $12 \mathrm{~h}$ and the diameter of the zone of inhibition was measured on 8-12 $\mathrm{h}$ and the final diameter was presented in $\mathrm{mm}$. Test results were reported as resistant, semi-sensitive, and sensitive according to the size of the zones of inhibition (12).

\section{Cholesterol Reduction Test}

In order to evaluate the ability of microorganisms for cholesterol hydrolysis, $0.2 \mathrm{~mL}$ of microorganism suspension in broth medium was inoculated to $20 \mathrm{~mL}$ of culture medium containing $100 \mu \mathrm{g} / \mathrm{mL}$ of cholesterol oxalate and was incubated at $37^{\circ} \mathrm{C}$ for 16 h. Afterwards, the tubes were centrifuged at $8000 \mathrm{rpm}$ for $5 \mathrm{~min}$ at room temperature. Next, $0.5 \mathrm{~mL}$ of the supernatant was transferred to a glass tube and was mixed with $3 \mathrm{~mL}$ ethanol 95\% followed by adding $2 \mathrm{~mL}$ potassium hydroxide $50 \%$. The mixture was homogenized by $1 \mathrm{~min}$ vortex after the addition of each component.

The tubes were heated in a water bath of $60^{\circ} \mathrm{C}$ for $10 \mathrm{~min}$ and were cooled at room temperature. In the next step, $5 \mathrm{~mL}$ hexane was added to each tube and vortex was used for $20 \mathrm{sec}$ followed by adding $3 \mathrm{~mL}$ of distilled water and $1 \mathrm{~min}$ vortex. The tubes were left at room temperature for 15 min or until the water and organic phases were completely separated. Afterwards, $2.5 \mathrm{~mL}$ of hexane layer (the upper layer) was poured into clean tubes and hexane was evaporated at $65^{\circ} \mathrm{C}$ in a water bath.

The liquid remaining in the tubes was mixed with 4 $\mathrm{mL}$ of o-phthalaldehyde and was kept at room temperature for $10 \mathrm{~min}$. Next, $2 \mathrm{~mL}$ of sulfuric acid was added to each tube and was left at room temperature for $10 \mathrm{~min}$. the absorbance of samples was read using a spectrophotometer at the wavelength of $550 \mathrm{~nm}$ versus blank (13).

\section{Bile Salt Hydrolase Activity Assay}

The zone of deoxycholic acid precipitation around the colonies in the culture medium containing the salt of bile acids was evaluated. To this aim, $10 \mu \mathrm{L}$ of microorganism suspension was cultured on the surface of the MRX agar plate and was incubated at a suitable temperature. In the case of hydrolase activity, white precipitation and scattered zones surrounding colonies were clear. When these zones could not be observed, $0.037 \%$ calcium chloride could be added to the culture and blank discs dipped in $10 \mu \mathrm{L}$ bacterial suspension are applied on the plate surface. A zone of white precipitation around the disc indicates bile salt hydrolysis by the tested bacterium (14).

\section{Identification of the Isolates Selected by Probiotic} Tests

Seven isolates with relative priority to other isolates in probiotic tests were identified by the DNA sequencing of the $16 \mathrm{~s}$ ribosomal region. The mentioned region was amplified by polymerase chain reaction (PCR) utilizing Gradient Palm-Cycler (Corbett Life Science Pty. Ltd., Australia). General primers with the forward sequence of $5^{\prime}$ GAG AGT TTG ATC CTG GCT CAG $3^{\prime}$ and the reverse sequence of $5^{\prime}$ GAA AGG AGG TGA TCC AGC CG 3' were applied for amplifying the intended segment (15).

The reaction set was as follow: $2 \mathrm{~min}$ at $95^{\circ} \mathrm{C}, 35$ cycles at $95^{\circ} \mathrm{C}$ for $45 \mathrm{sec}, 45 \mathrm{sec}$ at $53^{\circ} \mathrm{C}, 60 \mathrm{sec}$ at $72^{\circ} \mathrm{C}$ 
and the final step of $3 \mathrm{~min}$ at $73^{\circ} \mathrm{C}$. The reaction product was electrophoresed on $0.8 \%$ agarose gel, the segment was extracted from the gel and after confirming the band length and concentration determination, it was sent to Microsynth, Switzerland for sequencing.

\section{Statistical Analysis}

The obtained data were analyzed as a random design with 3 repeats using SAS version 9.2. Moreover, Excel software version 2010 was used to draw the graphs.

\section{Results}

\section{Resistance to Bile Salts and Acid}

Findings of catalase test, gram staining, and the microscopic examination of isolates revealed that 15 colonies were bacilliform, gram positive, and catalasenegative, which were selected for probiotic tests and were encoded as S1-S15. The results of bile salts resistance assay at the concentrations of $0.3 \%, 0.7 \%$, and $1 \%$ following $8 \mathrm{~h}$ of incubation are demonstrated in Table 1.
Moreover, the findings of testing X-gal $0.3 \%$ for the 15 intended isolates showed that S5 was highly resistant and S8, S9, S11, and S14 were resistant. In addition, S1, S2, S3, S4, S6, S7, S10, S13, and S15 isolates were sensitive. In media containing $0.7 \%$ and $1 \%$ bile salts. The isolates S8, S5, and S11 were resistant, while S9 and S14 were found as sensitive. As a result, $20 \%$ of the isolates were resistant to $0.7 \%$ and $1 \%$ concentrations of bile salts and S8, S5, and S11 were known as bile-resistant isolates.

Test of resistance to acid revealed that S15, S14, $\mathrm{S} 13, \mathrm{~S} 10, \mathrm{~S} 2$, and S1 were not sufficiently resistant to $\mathrm{pH}=3$ following an hour of incubation at $37^{\circ} \mathrm{C}$ and had the viability percentage of zero. On the other hand, S11 and S12 had the highest viability rate of $96 \%$ followed by the isolates S9, S8, S7, S6, S5, S4, and S3 with the viability of $55 \%-60 \%$ after an hour of incubation. The resistant isolates in the latter step were tested at $\mathrm{pH}=2.5$. The lowest and highest viability percentages following two hours of incubation at $\mathrm{pH}=2.5$ were observed for S12 and S9, respectively. Afterwards, the resistant isolates in this stage were tested at $\mathrm{pH}=2$. The results indicated that the most resistant bacteria to acid $\mathrm{pH}$ were S11, S7, and S5.

Table 1. Inhibition coefficient of samples in the assay of resistance to $0.3 \%, 0.7 \%$, and $1 \%$ bile salts after $8 \mathrm{~h}$ incubation at 37

\begin{tabular}{|c|c|c|c|c|c|c|}
\hline Bacterium code & $\begin{array}{c}\text { Inhibition } \\
\text { coefficient } \\
0.3 \%\end{array}$ & Final result & $\begin{array}{c}\text { Inhibition } \\
\text { coefficient } \\
\mathbf{0 . 7 \%}\end{array}$ & Final result & $\begin{array}{c}\text { Inhibition } \\
\text { coefficient } \\
1 \%\end{array}$ & Final result \\
\hline S1 & 1 & Sensitive & - & - & - & - \\
\hline S2 & 0.91 & Sensitive & - & - & - & - \\
\hline S3 & 1 & Sensitive & - & - & - & - \\
\hline S4 & 1 & Sensitive & - & - & - & - \\
\hline S5 & 0.19 & Highly resistant & 0.39 & Resistant & 0.14 & Resistant \\
\hline S6 & 1 & Sensitive & - & - & - & - \\
\hline S7 & 0.84 & Sensitive & - & - & - & - \\
\hline S8 & 0.31 & Resistant & 0.29 & Resistant & 0.28 & Resistant \\
\hline S9 & 0.37 & Resistant & 0.98 & Sensitive & 0.74 & Sensitive \\
\hline $\mathbf{S 1 0}$ & 1 & Sensitive & - & - & - & - \\
\hline S11 & 0.43 & Resistant & 0.24 & Resistant & 0.43 & Resistant \\
\hline S12 & 0.85 & Sensitive & - & - & - & - \\
\hline S13 & 0.53 & Sensitive & - & - & - & - \\
\hline S14 & 0.24 & Resistant & 0.62 & Sensitive & 1 & Sensitive \\
\hline S15 & 1 & Sensitive & - & - & - & - \\
\hline
\end{tabular}


Resistance to gastric juice was evaluated in $0,30,60$, 90, and $120 \mathrm{~min}$ (Figure 1A). In this assay, isolates S5, S7, and S11 were tested as the isolates selected by acid test and S5, S8, and S11 as the isolates chosen by the bile resistance test. However, S14 was examined due to resistance to $0.3 \%$ bile and isolates $\mathrm{S} 3, \mathrm{~S} 4, \mathrm{~S} 6$, S9, and S12 were assessed because of resistance to $\mathrm{pH}=3$.

The results are summarized in Figure 1 . As could be observed, isolates S4, S14, and S6 had the lowest resistance to the simulated conditions of the stomach as viability reached zero after $30 \mathrm{~min}$. isolates $\mathrm{S8}, \mathrm{S9}$, and $\mathrm{S} 12$, which were resistant to $\mathrm{pH}=2.5$ but sensitive to $\mathrm{pH}=2$, were destroyed after $120 \mathrm{~min}$ of exposure to simulated gastric conditions. The isolates resistant to $\mathrm{pH}=2$, including $\mathrm{S7}, \mathrm{S} 11$, and $\mathrm{S} 5$ were the most resistant bacteria to gastric simulated conditions following $2 \mathrm{~h}$ of incubation. However, S7 and S11 have significantly higher viability than S5 $(P<0.05)$ as they showed the viability of $62 \%, 59 \%$, and $40 \%$, respectively.

Resistance to intestinal juice was assessed on 0, 30, 60,90 , and $120 \mathrm{~min}$ (Figure 1B). As demonstrated, the
S6 isolate had the lowest resistance to the simulated conditions of the intestine as the viability reached zero in $30 \mathrm{~min}$. The viability of isolates S3 and S9 was zero following $60 \mathrm{~min}$. in the present study, S3 and S9 were reported to be sensitive to the bile concentration of $0.3 \%$ and $0 \%$, respectively. Viability of S4, S7, S12, and $\mathrm{S} 14$ reached zero in $90 \mathrm{~min}$, all of which were sensitive to $0.3 \%$ bile except S14, which was found to be sensitive to $0.7 \%$ bile.

Finally, S5 and S11 isolates were able to tolerate intestinal simulated conditions with a $50 \%$ decrease in viability in $120 \mathrm{~min}$. however, the mentioned isolates were not significantly different in terms of viability $(P>0.05)$. Viability of $\mathrm{S} 8$ was zero after $120 \mathrm{~min}$ showing the lower resistance of this isolate, compared to S5 and S11.

Table 2 indicates the findings of the medium $\mathrm{pH}$ reduction test. Isolates S7 and S10 caused the highest and lowest $\mathrm{pH}$ decrease, respectively. Furthermore, isolates S3, S4, and S5 were not significantly different from $\mathrm{S} 7$ in this regard $(P>0.05)$.
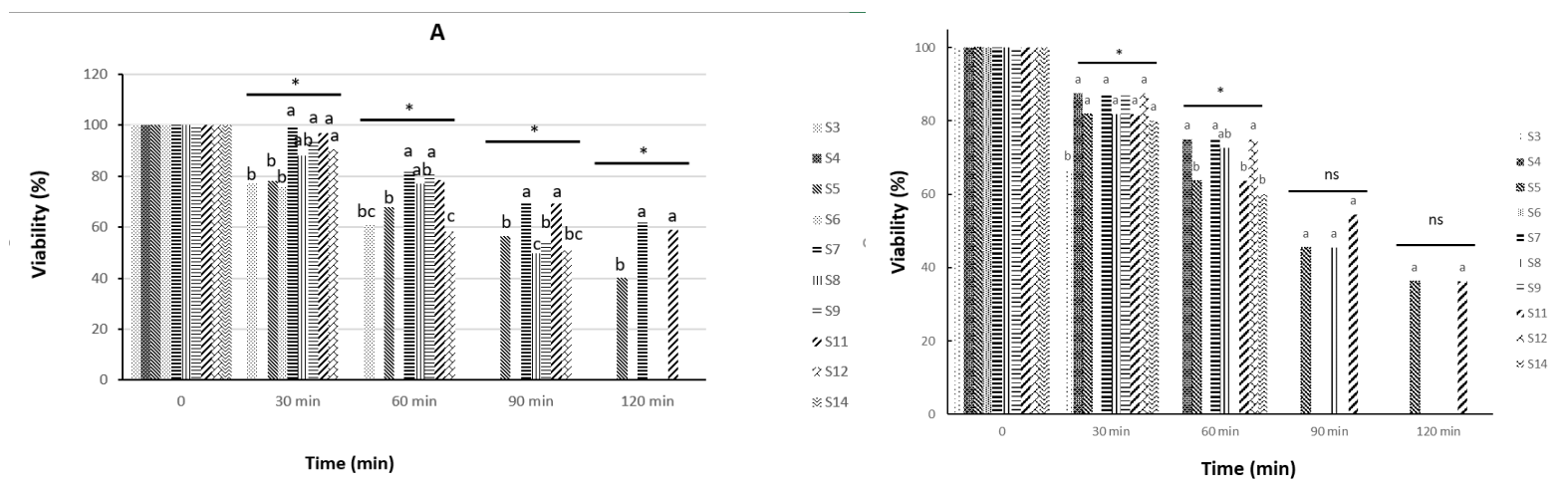

Figure 1. Viability percentage of the samples in the simulated conditions of gastric juice (A) and intestinal juice (B) during $2 \mathrm{~h}$ of incubation at 37 . Different letters indicate significant difference among various treatments $(p<0.05)$.

Table 2. Percentage of medium $\mathrm{pH}$ reduction by bacterial isolates derived from Naein traditional dairy product after $24 \mathrm{~h}$ of incubation at 37

\begin{tabular}{|c|c|c|c|}
\hline Bacterium code & Final pH & pH reduction percentage & \multicolumn{2}{c|}{ Ranking } \\
\hline S1 & 5.67 & $19.9^{\mathrm{cd}}$ & 11 \\
\hline S2 & 4.98 & $41.6^{\mathrm{ab}}$ & 3 \\
\hline S3 & 3.63 & $39.2^{\mathrm{ab}}$ & 5 \\
\hline S4 & 3.78 & $40.9^{\mathrm{ab}}$ & 4 \\
\hline S5 & 3.67 & $26^{\mathrm{bcd}}$ & 1 \\
\hline S6 & 4.6 & $57^{\mathrm{a}}$ & 14 \\
\hline
\end{tabular}




\begin{tabular}{|c|c|c|c|}
\hline Bacterium code & Final pH & pH reduction percentage & Ranking \\
\hline S9 & 4.19 & $32.6^{\mathrm{bc}}$ & 7 \\
\hline S10 & 5.94 & $4.5^{\mathrm{e}}$ & 15 \\
\hline S11 & 3.39 & $45.4^{\mathrm{b}}$ & 2 \\
\hline S12 & 5.17 & $16.8^{\mathrm{d}}$ & 12 \\
\hline S13 & 3.91 & $37.1^{\mathrm{bc}}$ & 6 \\
\hline S14 & 4.78 & $23.1^{\mathrm{bcd}}$ & 9 \\
\hline S15 & 4.89 & $21.3^{\mathrm{bcd}}$ & 10 \\
\hline P-value & & 0.001 & \\
\hline \multicolumn{2}{|c|}{ Mean standard error } & 4.023 & \\
\hline
\end{tabular}

Values with different superscript letters in the column mean the significant difference between treatments $(P<0.05)$

\section{Antimicrobial Activity}

Findings of antimicrobial activity tests are demonstrated in Table 3. The highest antimicrobial effect was observed for S4 and S9 isolates $(P<0.05)$. In other words, these isolates are the best choices for inhibiting Salmonella typhimurium. The bacterium Pseudomonas aeruginosa was significantly better inhibited by S4, S5, S12, and S14, compared to other isolates $(P<0.05)$. Isolates $\mathrm{S} 3, \mathrm{~S} 6$, and S8 significantly inhibited Escherichia coli $(P<0.05)$. Moreover, Staphylococcus aureus was significantly inhibited by $\mathrm{S7}$ and the yeast Candida albicans were inhibited by S3 and S14 $(P<0.05)$.

Table 3. Antimicrobial activity and ranking of isolates based on the diameter $(\mathrm{mm})$ of the zone against pathogen bacteria

\begin{tabular}{|c|c|c|c|c|c|c|c|c|c|c|}
\hline \multirow[b]{2}{*}{$\begin{array}{l}\text { TBacterium } \\
\text { code }\end{array}$} & \multicolumn{2}{|c|}{$\begin{array}{l}\text { Salmonella } \\
\text { typhimurium }\end{array}$} & \multicolumn{2}{|c|}{ Escherichia coli } & \multicolumn{2}{|c|}{ Staphylococcus aureus } & \multicolumn{2}{|c|}{$\begin{array}{c}\text { Pseudomonas } \\
\text { aeruginosa }\end{array}$} & \multicolumn{2}{|c|}{ Candida albicans } \\
\hline & Ranking & $\begin{array}{c}\text { Zone } \\
\text { diamet } \\
\text { er }\end{array}$ & $\begin{array}{c}\text { Ranki } \\
\text { ng }\end{array}$ & $\begin{array}{c}\text { Zone } \\
\text { diameter }\end{array}$ & $\begin{array}{c}\text { Ranki } \\
\text { ng }\end{array}$ & $\begin{array}{c}\text { Zone } \\
\text { diameter }\end{array}$ & $\begin{array}{c}\text { Ranki } \\
\text { ng }\end{array}$ & $\begin{array}{c}\text { Zone } \\
\text { diameter }\end{array}$ & $\begin{array}{c}\text { Ranki } \\
\text { ng }\end{array}$ & $\begin{array}{c}\text { Zone } \\
\text { diameter }\end{array}$ \\
\hline S3 & 8 & $12^{\mathrm{bc}}$ & 2 & $23.5^{\mathrm{a}}$ & 6 & $17^{\mathrm{ab}}$ & 5 & $19.5^{\mathrm{ab}}$ & 2 & $23^{\mathrm{a}}$ \\
\hline S4 & 2 & $21.5^{\mathrm{a}}$ & 10 & $9^{\mathrm{bc}}$ & 4 & $19^{\mathrm{ab}}$ & 4 & $21.5^{\mathrm{a}}$ & 10 & $7.5^{\mathrm{b}}$ \\
\hline S5 & 5 & $15^{\mathrm{bc}}$ & 8 & $13^{\mathrm{abc}}$ & 8 & $9^{c}$ & 3 & $22^{\mathrm{a}}$ & 6 & $17.5^{\mathrm{ab}}$ \\
\hline S6 & 10 & $8.5^{\mathrm{cd}}$ & 3 & $21.75^{\mathrm{a}}$ & 7 & $13^{\mathrm{bc}}$ & 6 & $18.75^{\mathrm{ab}}$ & 9 & $8^{\mathrm{b}}$ \\
\hline S7 & 6 & $14.25^{\mathrm{bc}}$ & 9 & $12.25^{\mathrm{abc}}$ & 1 & $22^{\mathrm{a}}$ & 8 & $18^{\mathrm{ab}}$ & 4 & $18.75^{\mathrm{ab}}$ \\
\hline S8 & 4 & $18.5^{\mathrm{ab}}$ & 1 & $25^{\mathrm{a}}$ & 10 & $8^{c}$ & 9 & $14^{\mathrm{ab}}$ & 7 & $17^{\mathrm{ab}}$ \\
\hline S9 & 1 & $23.5^{\mathrm{a}}$ & 6 & $18^{\mathrm{ab}}$ & 3 & $19.5^{\mathrm{ab}}$ & 7 & $18.5^{\mathrm{ab}}$ & 5 & $18.5^{\mathrm{ab}}$ \\
\hline S11 & 9 & $10^{\mathrm{bc}}$ & 11 & $6.5^{\mathrm{c}}$ & 11 & $7.5^{\mathrm{c}}$ & 11 & $7.5^{\mathrm{c}}$ & 8 & $14^{\mathrm{b}}$ \\
\hline S12 & 3 & $19^{\mathrm{ab}}$ & 5 & $19^{\mathrm{ab}}$ & 5 & $18.5^{\mathrm{ab}}$ & 1 & $25^{\mathrm{a}}$ & 11 & $7^{b}$ \\
\hline S14 & 11 & $7.25^{\mathrm{cd}}$ & 7 & $17.5^{\mathrm{abc}}$ & 9 & $8.5^{\mathrm{c}}$ & 2 & $22.5^{\mathrm{a}}$ & 1 & $23.5^{\mathrm{a}}$ \\
\hline \multirow{2}{*}{ Antibiotic } & \multicolumn{2}{|c|}{ Cefalexin } & \multicolumn{2}{|c|}{ Amoxicillin } & \multicolumn{2}{|c|}{ Streptomycin } & \multicolumn{2}{|c|}{ Erythromycin } & \multicolumn{2}{|c|}{ Vancomycin } \\
\hline & 7 & $12.5^{\mathrm{bc}}$ & 4 & $20^{\mathrm{ab}}$ & 2 & $20^{\mathrm{ab}}$ & 10 & $11.25^{\mathrm{bc}}$ & 3 & $19^{\mathrm{ab}}$ \\
\hline P-value & & 0.0001 & & 0.0001 & & 0.045 & & 0.049 & & 0.038 \\
\hline Mean standard er & & 3.351 & & 3.821 & & 4.231 & & 2.986 & & 3.593 \\
\hline
\end{tabular}

Values with different superscript letters in the column mean the significant difference between treatments $(P<0.05)$

\section{Antibiotic Resistance}

Table 4 demonstrates the results of antibiotic resistance for bacterial isolates from Naein traditional dairy product based on the diameter of the zone $(\mathrm{mm})$. Most of the bacteria were sensitive or semi-sensitive to amoxicillin as
S3, S4, and S5 were sensitive and isolates S6, S8, and S9 were semi-sensitive to amoxicillin. On the other hand, eight isolates were resistant to vancomycin and cephalexin. Isolates S3, S4, S5, S7, S9, S11, S12, and S14 
were found to be resistant to vancomycin and S3, S5, S6, S7, S8, S11, S12, and S14 were resistant to cephalexin.

Table 4. antibiotic resistance of bacterial isolates from Naein traditional dairy product based on the diameter of the zone ( $\mathrm{mm}$ )

\begin{tabular}{|c|c|c|c|c|c|c|c|}
\hline $\begin{array}{l}\text { Isolate } \\
\text { code }\end{array}$ & $\begin{array}{c}\text { E15 } \\
\text { Erythromycin }\end{array}$ & $\begin{array}{c}\text { AMX } 25 \\
\text { Amoxicillin }\end{array}$ & $\begin{array}{c}\text { C30 } \\
\text { Chloramphenicol }\end{array}$ & $\begin{array}{c}\text { S10 } \\
\text { Streptomycin }\end{array}$ & $\begin{array}{c}\text { V30 } \\
\text { Vancomycin }\end{array}$ & $\begin{array}{c}\text { CN30 } \\
\text { Cefalexin }\end{array}$ & $\begin{array}{c}\text { FM300 } \\
\text { Nitrofurantoin }\end{array}$ \\
\hline S3 & Resistant & Sensitive & Resistant & Semi-sensitive & Resistant & Resistant & Semi-sensitive \\
\hline S4 & Sensitive & Sensitive & Sensitive & Resistant & Resistant & Sensitive & Resistant \\
\hline S5 & Resistant & Sensitive & Resistant & Resistant & Resistant & Resistant & Resistant \\
\hline S6 & Resistant & Semi-sensitive & Semi-sensitive & Resistant & Sensitive & Resistant & Resistant \\
\hline S7 & Resistant & Resistant & Resistant & Resistant & Resistant & Resistant & Resistant \\
\hline S8 & Resistant & Semi-sensitive & Resistant & Sensitive & $\begin{array}{c}\text { Semi- } \\
\text { sensitive }\end{array}$ & Resistant & Sensitive \\
\hline S9 & Resistant & Semi-sensitive & Semi-sensitive & Resistant & Resistant & $\begin{array}{l}\text { Semi- } \\
\text { sensitive }\end{array}$ & Resistant \\
\hline S11 & Sensitive & Resistant & Resistant & Resistant & Resistant & Resistant & - \\
\hline S12 & Resistant & Resistant & Resistant & Sensitive & Resistant & Resistant & Sensitive \\
\hline S14 & - & Resistant & Resistant & Resistant & Resistant & Resistant & Resistant \\
\hline
\end{tabular}

\section{Cholesterol Reduction}

Results of cholesterol reduction by the bacterial isolates of Naein dairy product after $16 \mathrm{~h}$ of incubation at $37^{\circ} \mathrm{C}$ are shown in Table 5. Isolates S5 and S11 were significantly different from other isolates with reductions of $99 \%$ and $98 \%$, respectively $(P<0.05)$. The S8 and S9 with cholesterol reduction of $87 \%$ and $80 \%$ were not significantly different from S5 and S11 $(P>0.05)$. Isolates S5, S11, and S8 had a suitable resistance to bile salts as could tolerate $1 \%$ of bile salts. The S9 and S14 could only tolerate $0.3 \%$ bile salt. Isolates S5 and S11 were reported to have suitable tolerance against acid conditions as could tolerate $\mathrm{pH}=2$. Furthermore, isolate $\mathrm{S} 12$ was found to be able to tolerate acidic conditions up to $\mathrm{pH}=2.5$. We observed that S5, S11, S8, and S9 has the highest cholesterol reduction levels. Isolate S12 was shown to impose the lowest impact on cholesterol reduction.

Table 5. cholesterol reduction percentage by bacterial isolates from Naein traditional dairy product after $16 \mathrm{~h}$ of incubation at $37^{\circ} \mathrm{C}$

\begin{tabular}{|c|c|c|}
\hline Bacterium code & Cholesterol reduction percentage & 1 \\
\hline S5 & $99.14^{\mathrm{a}}$ & 2 \\
\hline S8 & $87.32^{\mathrm{ab}}$ & 3 \\
\hline S9 & $80.5^{\mathrm{ab}}$ & 1 \\
\hline S11 & $98.41^{\mathrm{a}}$ & 4 \\
\hline S12 & $71.35^{\mathrm{b}}$ & 3 \\
\hline S14 & $76.28^{\mathrm{b}}$ & \\
\hline P-value & 0.012 & \\
\hline Mean standard error & $($ Over $95 \%$ rank 1, over $85 \%$ rank 2, over $75 \%$ rank 3, and over $70 \%$ rank 4$)$ \\
\hline
\end{tabular}

Values with different superscript letters in the column mean the significant difference between treatments $(P<0.05)$

Table 6 shows the findings of the bile salts hydrolase activity test. In this test, bile-resistant isolates (i.e., S5, S8, S9, S11, and S14), in addition to S12 as a negative control for controlling test accuracy were selected. The obtained results were reported as the measurement of the white zone produced by isolates in $\mathrm{mm}$.

According to our findings, isolates S8, S5, and S11 had orderly the largest zones $(P<0.05)$. Considering the cholesterol reduction test, these results could be 
expected because the latter isolates had the highest percentages of cholesterol reduction. Activity of bile acids hydrolyzing enzyme was observed for the isolates,

Table 6. Bile salts hydrolysis by the bacterial isolates of Naein traditional dairy product based on the diameter of zones

\begin{tabular}{|c|c|c|c|}
\hline Bacterium code & Zone diameter (mm) & Strong, weak, moderate & Ranking \\
\hline S5 & $3.5^{\mathrm{ab}}$ & Strong & 2 \\
\hline S8 & $4^{\mathrm{a}}$ & Strong & 1 \\
\hline S9 & $2.5^{\mathrm{b}}$ & Moderate & 4 \\
\hline S11 & $3^{\mathrm{ab}}$ & Strong & 3 \\
\hline $\mathrm{S} 12$ & $1.5^{\mathrm{b}}$ & Weak & 6 \\
\hline S14 & $2.25^{\mathrm{b}}$ & Moderate & 5 \\
\hline P-value & 0.032 & & \\
\hline Mean standard error & 0.574 & & \\
\hline
\end{tabular}

Values with different superscript letters in the column mean the significant difference between treatments $(P<0.05)$

\section{Molecular Identification of Bacterial Isolates with Probiotic Characteristics}

Bacterial isolates S5, S8, S9, S11, and S14 had the potential for cholesterol reduction and bile salts hydrolysis. Moreover, S3 had higher antimicrobial properties and $\mathrm{S} 7$ was highly resistant to $\mathrm{pH}$ variations with strong antimicrobial impact. As a result, the aforementioned isolates were investigated using PCR for which could reduce blood cholesterol. Therefore, a correlation was suggested between these two features.

Table 7. Sequence BLAST of ribosomal 16s region of the DNAs of the isolates from Naein traditional dairy product according to the databases of NCBI and eztaxon

\begin{tabular}{|c|c|c|c|c|c|c|}
\hline $\begin{array}{l}\text { Bacterium } \\
\text { code }\end{array}$ & Species in Taxon & Isolate & $\begin{array}{l}\text { Similarity } \\
(\%)\end{array}$ & Species in NCBI & Isolate & $\begin{array}{l}\text { Similarity } \\
(\%)\end{array}$ \\
\hline S3 & $\begin{array}{l}\text { Lactobacillus } \\
\text { pentosus }\end{array}$ & $\begin{array}{c}\text { DSM } \\
20314(\mathrm{~T})\end{array}$ & 100 & $\begin{array}{l}\text { Lactobacillus } \\
\text { Plantarum }\end{array}$ & $\begin{array}{c}\text { Strain } \mathrm{H}_{1}, 16 \mathrm{~S} \text { ribosomal } \\
\text { RNA gene }\end{array}$ & 100 \\
\hline S5 & $\begin{array}{l}\text { Lactobacillus } \\
\text { Crustorum }\end{array}$ & $\begin{array}{c}\text { LMG } \\
23699(\mathrm{~T})\end{array}$ & 99.93 & $\begin{array}{l}\text { Lactobacillus } \\
\text { Crustorum }\end{array}$ & $\begin{array}{l}\text { Strain B481,16S } \\
\text { ribosomal RNA gene }\end{array}$ & 100 \\
\hline S7 & $\begin{array}{l}\text { Lactobacillus } \\
\text { fermentum }\end{array}$ & $\begin{array}{c}\text { CECT } \\
562(\mathrm{~T})\end{array}$ & 99.71 & $\begin{array}{l}\text { Lactobacillus } \\
\text { fermentum }\end{array}$ & $\begin{array}{c}\text { Strain } \\
\text { APBSMLB166,16S } \\
\text { ribosomal RNA gene }\end{array}$ & 99.71 \\
\hline S8 & $\begin{array}{l}\text { Lactobacillus } \\
\text { Pentosus }\end{array}$ & $\begin{array}{c}\text { DSM } \\
20314(T)\end{array}$ & 99.93 & $\begin{array}{l}\text { Lactobacillus } \\
\text { Plantarum }\end{array}$ & $\begin{array}{l}\text { Strain PS7319,16S } \\
\text { ribosomal RNA gene }\end{array}$ & 100 \\
\hline S9 & $\begin{array}{l}\text { Lactobacillus } \\
\text { fermentum }\end{array}$ & $\begin{array}{l}\text { CECT } \\
562(\mathrm{~T})\end{array}$ & 99.36 & $\begin{array}{l}\text { Lactobacillus } \\
\text { fermentum }\end{array}$ & $\begin{array}{l}\text { Strain 10-18 16S } \\
\text { ribosomal RNA gene }\end{array}$ & 99.36 \\
\hline S11 & Lactobacillus brevis & $\begin{array}{c}\text { ATCC } \\
14869(\mathrm{~T})\end{array}$ & 99.86 & $\begin{array}{l}\text { Lactobacillus } \\
\text { brevis }\end{array}$ & $\begin{array}{l}\text { Strain NOS7311 16S } \\
\text { ribosomal RNA gene }\end{array}$ & 100 \\
\hline S14 & Lactobacillus brevis & $\begin{array}{c}\text { ATCC } \\
14869(\mathrm{~T})\end{array}$ & 99.93 & $\begin{array}{c}\text { Lactobacillus } \\
\text { brevis }\end{array}$ & $\begin{array}{l}\text { Strain SKB1021 16S } \\
\text { ribosomal RNA gene }\end{array}$ & 100 \\
\hline
\end{tabular}

\section{Discussion}

Evaluation of resistance to acidic conditions revealed that six out of 15 bacterial isolates had a suitable resistance to $\mathrm{pH}=2.5$. Sharifi et al. (2017) investigated probiotic characteristics of the bacteria isolated from traditional yogurt in Yazd, Iran in $\mathrm{pH}=2.5-3$. They reported lower resistance of Bifidobacteria, in comparison with Lactobacilli. In addition, they showed that Lactobacillus isolates were more resistant to acidic conditions than Streptococcus and Enterococcus. 16sr RNA for molecular identification. Results of sequencing were compared with the sequences in gene banks, including EzBioCloud (eztaxon) and NCBI. The final findings of sequencing for the evaluated isolates are summarized in Table 7. Consequently, Naein traditional dairy product had diverse genera of Lactobacillus, among which L. pentosus, L. crustorum, L. brevis, and $L$. fermentum were identified. 
$120 \mathrm{~min}$ than $60 \mathrm{~min}$. It could be attributed to the higher lysis rate of the bacterial cell wall by the acid in longer contact. Majidzadeh et al. (2011) investigated the impact of time and $\mathrm{pH}$ on the reduction of isolates activity. They reported that the isolates had a 55\%-60\% decrease in viability following $2 \mathrm{~h}$ of incubation at $\mathrm{pH}=2$, which was in line with the findings of the current study (17).

Results of bile salts resistance assay showed that $60 \%$ of the isolates were sensitive to bile salts. Sharifi et al. (2017) tested 24 Lactobacillus isolates from traditional yogurt of Yazd, Iran using bovine bile extract $0.3 \%$ for 8 h. They reported 10,2 , and 12 isolates as resistant, highly resistant, and sensitive, respectively. Their results are consistent with the present investigation. Hajighassemi et al. (2016) recognized five resistant isolates following 8 $\mathrm{h}$ of incubation beside $0.3 \%$ bile salts and two resistant isolates utilizing $0.7 \%$ bile salts (8).

Isolates S8, S9, and S12, which were resistant to $\mathrm{pH}=2.5$ but sensitive to $\mathrm{pH}=2$, were destroyed after 120 min of exposure to gastric simulated conditions. As expected, isolates S7, S11, and S5, which were resistant to $\mathrm{pH}=2$, were the most resistant bacteria to gastric simulated conditions after $2 \mathrm{~h}$ of incubation as they indicated $62 \%, 59 \%$, and $40 \%$ viability. Gastric pepsin enzyme affects bacterial cell walls due to proteolytic activity and destroys the bacteria. A study on probiotic characteristics revealed that the viability of $L$. acidophilus and $\mathrm{L}$. rhamnosus $\mathrm{GG}$ had a $60 \%$ reduction in gastric simulated conditions under treatment by the whole salt with pepsin enzyme for $120 \mathrm{~min}$.

In intestinal simulated conditions, S6 had the lowest resistance as expected because the viability of this bacterium reached zero after $60 \mathrm{~min}$ in gastric simulated conditions and was not resistant to $\mathrm{pH}=.5$. Moreover, this bacterium could not tolerate $0.3 \%$ bile salts and was reported as sensitive. Another investigation on the viability of L. rhamnosus GG in intestinal simulated conditions demonstrated that the most reduction in viability occurred after 30 min of exposure to intestinal simulated conditions. This could be attributed to the sudden shock due to bacterial exposure to high $\mathrm{pH}$ and bile salts indicating the higher sensitivity of this bacterium to intestinal simulated conditions (19).

Evaluation of antimicrobial effects showed that isolates S9 and S4 were the best options for inhibiting S. typhimurium, S12 and S14 were the best for P. aeruginosa and isolates S3 and S8 were the most effective for $\mathrm{E}$. coli. In addition, the best isolates for the inhibition of S. aureus were S7 and S9 and for C. albicans yeast were S3 and S14. The antimicrobial impact of some Lactobacillus isolates was correlated with $\mathrm{pH}$ decrease (20). However, the antimicrobial properties cannot be completed attributed to $\mathrm{pH}$ reduction. The secretion of bacteriocins as antibacterial compounds by Lactobacilli is believed to play role in this regard (21).
Numerous studies are still being conducted in this regard. Sharifi et al. (2017) reported a strong antimicrobial activity for L. rhamnosus and L. fermentum against the pathogenic bacteria $\mathrm{S}$. typhimurium, $\mathrm{S}$. aureus, and E. coli. An investigation was performed on the antimicrobial activity of Lactobacillus isolates from two samples of traditional yogurt. It was found that $\mathrm{L}$. acidophilus with the mean diameter of $14.68 \mathrm{~mm}$ for the zone of inhibition against $\mathrm{S}$. typhimurium and $\mathrm{S}$. aureus along with L. plantarum with the mean diameter of 12.37 $\mathrm{mm}$ against $P$. aeruginosa had the highest antimicrobial activity. The mentioned findings were in line with the results of the present study.

A considerable aspect in terms of the safety of probiotics is antibiotic resistance. This is the potential risk of the transfer of antibiotic resistance genes among Lactobacilli. Following passing acidic conditions and bile in the digestive system, the transfer of antibiotic resistance genes located on plasmid to the flora of the digestive system and even intestinal epithelial cells is possible. As a result, the safety of using such bacteria as probiotics is reduced (22).

A study was performed on the resistance of Lactobacillus isolates from Mazandaran, Iran traditional cheese to the common antibiotics. It was observed that most of the isolates were resistant to streptomycin, vancomycin, and gentamycin, sensitive to amoxicillin, and semi-sensitive to nitrofurantoin (23), which is consistent with our results.

Tissay et al. (2014) in a clinical study, reported the influence of $\mathrm{L}$. rhamnosus and $\mathrm{L}$. bulgaricus on the diminish of blood cholesterol in rats. Furthermore, they stated that Pediococcus acidilactici could cause a $20 \%$ reduction in serum total cholesterol of rats (14). Shahat et al. (2016) evaluated the impact of probiotic isolates from a traditional fermented dairy product on health. These authors demonstrated that in laboratory conditions, isolates L. plantarum and L. brevis could reduce cholesterol (13).

Simultaneous with the enzymatic activity for further hydrolysis of bile salts by the isolates, cholesterol reduction and detoxification occurs in the digestive system, especially the liver. Comparison of the potential for bile salts indicates that the higher the ability of bacteria for hydrolysis of these salts, the better the reduction and detoxification by the digestive system and liver is performed (24)

Mirlohi et al. (2010) in a clinical study on laboratory mice, noted that L. plantarum was influential in the reduction of serum cholesterol. They considered having bile-hydrolyzing enzyme as one of the factors for cholesterol reduction by probiotic isolates, which caused an $8 \%-10 \%$ decrease in blood cholesterol (10). 
Tissay et al. (2014) investigated bile salts derived from bovine bile in the diet of mice. They showed that $L$. acidophilus and $\mathrm{L}$. fermentum led to the highest rate of serum cholesterol reduction, which was in line with the findings of the present study (isolate L. fermentum, S8). They attributed the decrease in serum cholesterol to the production of bile-hydrolyzing enzymes by Lactobacillus isolates (14)

\section{Conclusion}

According to the findings of the current study, koome is highly potential for isolating probiotic isolates and contains active probiotic isolates Therefore, in the present investigation, isolates with probiotic characteristics were derived from this fermented dairy product of Naein. Isolates obtained from this product were demonstrated to have diverse potentials for healthy effects on the digestive system, such as having anti-pathogen activity, inducing acidic conditions, and hydrolyzing cholesterol.

\section{Conflict of Interest}

The authors declared no conflict of interest. 


$$
\begin{aligned}
& \text { مجله ميكروبشناسى يزشكى ايران } \\
& \text { سال ه1 ـ شماره ا - بهمن و اسفند 99 } 1 \text { 11 }
\end{aligned}
$$

\title{
جداسازى باكترىهاى لاكتوباسيل با قابليت بروبيوتيكى از محصول لبنى سنتى نائين (كومه)
}

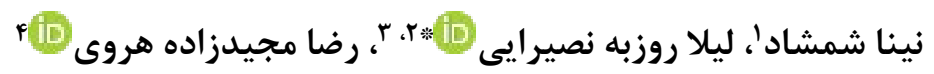

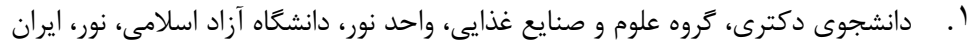

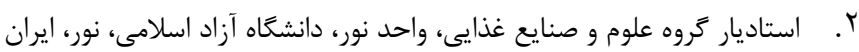

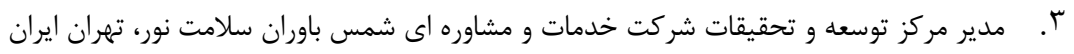

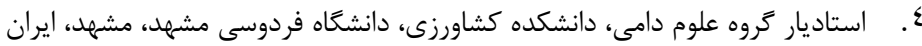

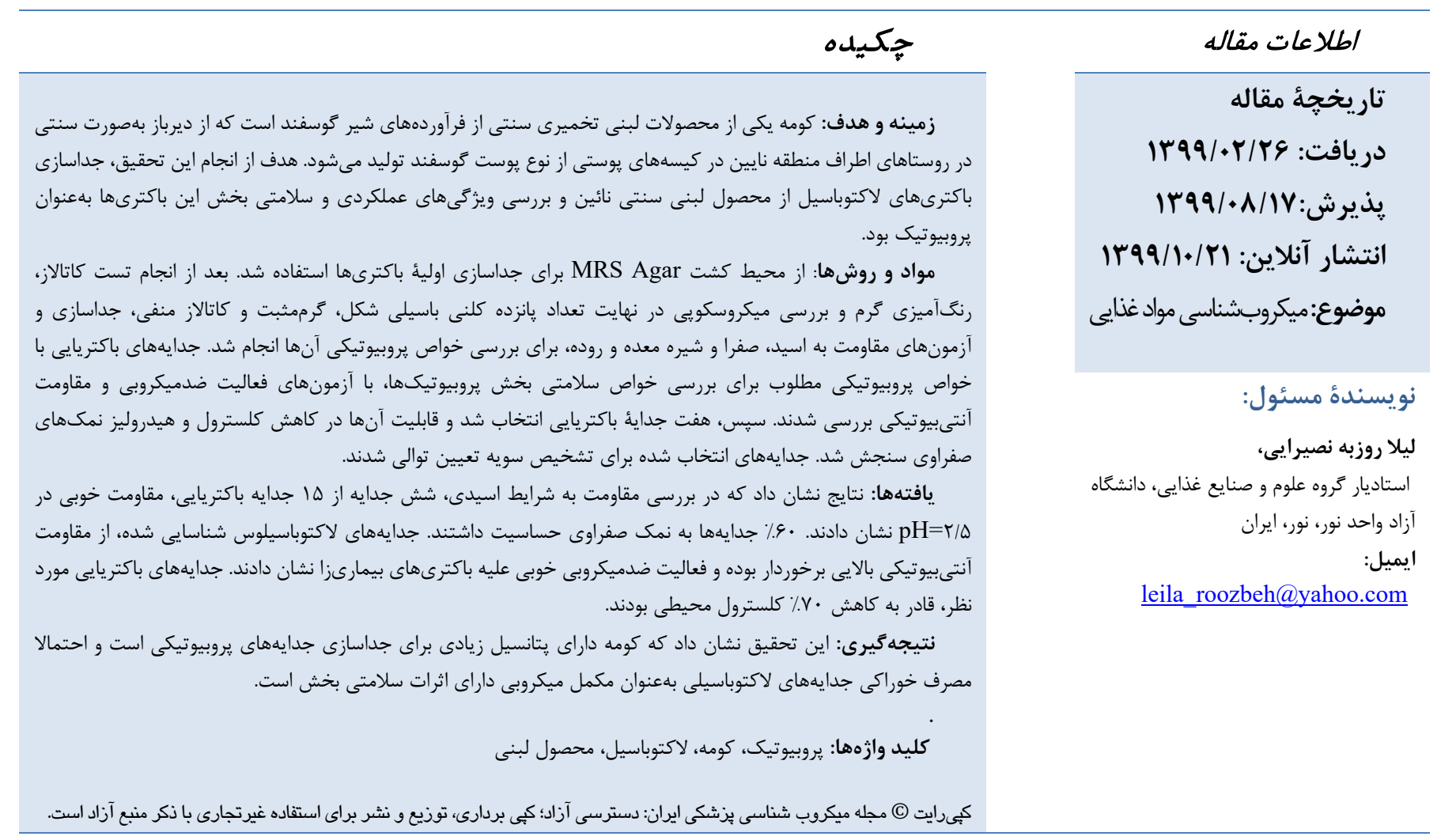

مقلدمه

يروبيوتيكها از اين جهت كه منجر به تحريك رشد ميكرواركانيسمهاى مفيد روده، كاهش جمعيت باكترىهاى مضر و كمك به مكانيسمهاى دفاعى طبيعى بدن مىشوند، حائز اهميت هستند(ب). اثرات سودمند باكترىهاى اسيدلاكتيك جداشده از محصولات لبنى سنتى بومى جهت ييشخيرى و درمان بيمارىها، به اثبات رسيده است و تاكنون، اثرات جانبى منفى ناشى از مصرف آنها بلهعنوان يروبيوتيك مشاهده نشده

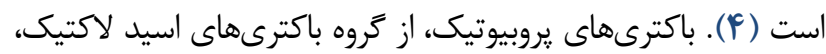

فرآوردههاى تخميرى مانند ماست، كفير، دوغ، ساوركرات، كامبوجا و ساير محصولات لبنى كه از قديم بهطور سنتى در ميان مردم ماندي

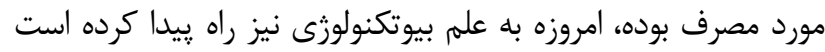
(1). علم : يروبيوتيك درمانى (Probiotic Therapy)، حاصل تكامل اين روند در ميكروبيولوزى غذايى بوده كه به تفسير اثرات سودمند

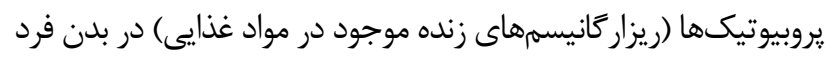

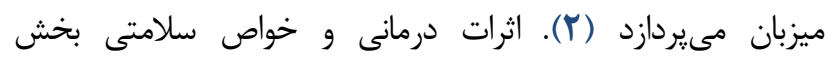


از انجام اين تحقيق، جداسازى باكترىهاى لاكتوباسيل با قابليت

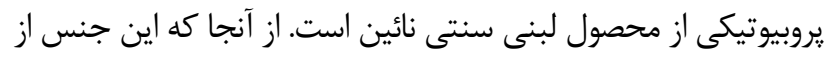

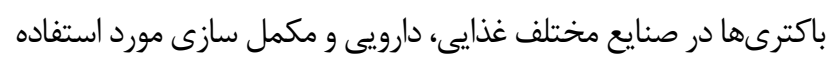

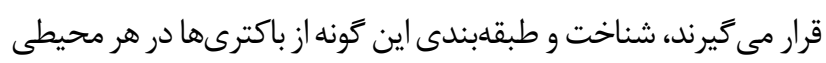
اطلاعات با ارزشى را در اختيار محققان قرار مىدهد.

\section{مواد و روشها}

\section{نمونه بردارى و كشت ميكروبى}

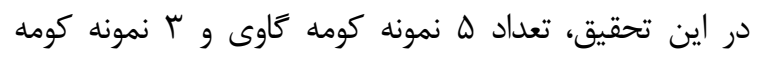

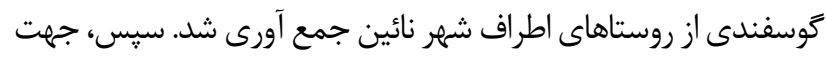

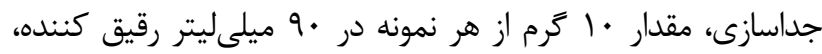

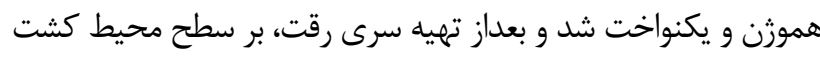

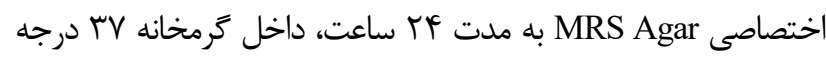
سلسيوس گرمخانهكذارى شدند. كلنىهاى رشد يافته بر سطح محيط كشت، جهت جداسازى باكترىهاى لاكتوباسيلوس از ساير اركانيسمها

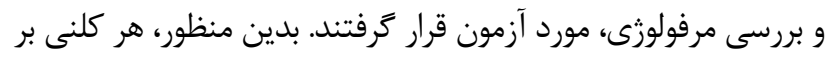

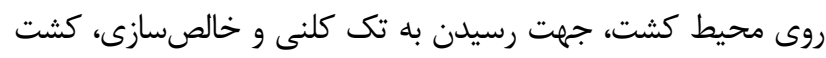
خطى داده شد. سيس، كشت خالصسازى شده بهعنوان كشت ذخيره

جهت آزمايشها نگَهدارى كَرديد (1).

\section{جداسازى باكترىهاى لاكتوباسيل}

آزمون كاتالاز براى بررسى توليد آنزيم كاتالاز، توسط باكترىهاى لإيل

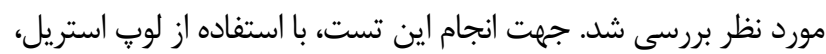

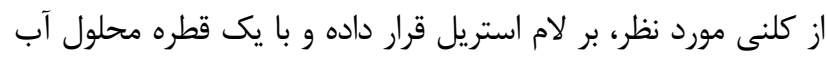

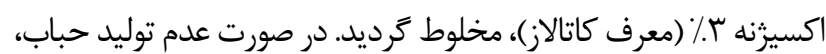
مىتوان كفت باكترى مورد نظر، توانايى توليد آنزيم كاتالاز را ندارد و

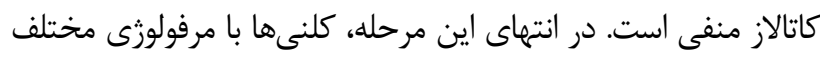

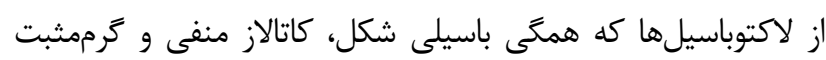

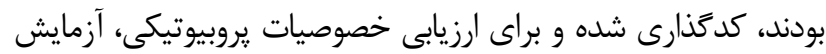

شدند و كشت سطحى از نمونهاى كدكذارى شده، تهيه شد (9).

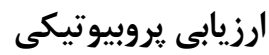

\section{مقاومت به شرايط اسيدى و صفرا}

بقاى ميكرواركانيسمها در محيط كشت مايع با pH هاى اسيدى

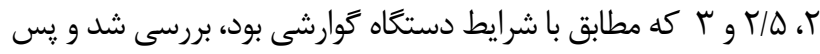

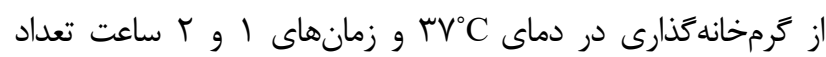

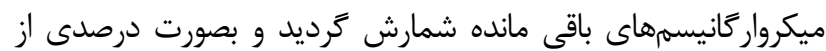

كروهى از باكترىهاى كرممثبت هستند كه در فلور ميكروبى دستگًاه

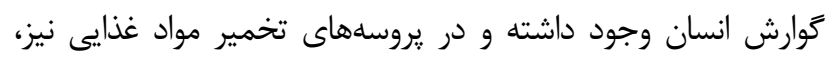

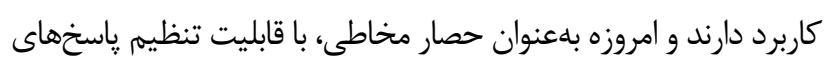

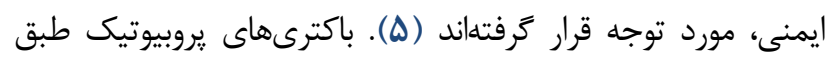

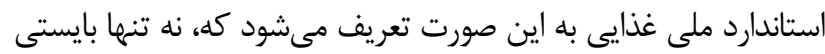

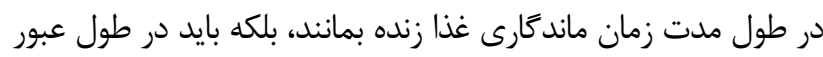

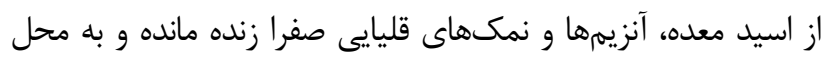
فعاليت خود (روده) برسند. به همين دليل، غذاهايى كه ادعا مىشوند داراى اثرات سلامتىبخش هستند، بايد به هنغام مصرف، حداقل حاوى درى

V • إ يروبيوتيك زنده، در هر ترم وزنى باشند (1).

لاكتوباسيلوسها براى اولين بار از شير جداسازى شدند و امروزه

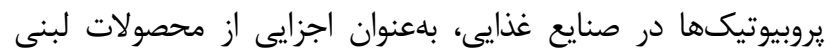

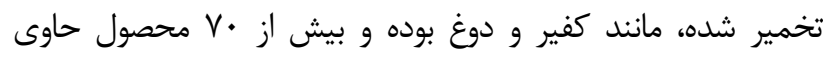

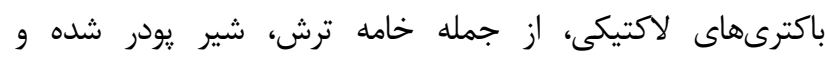

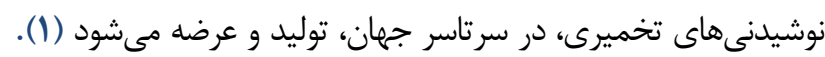

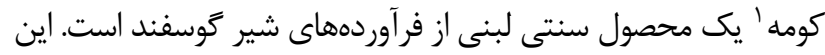
محصول به صورت سنتى در روستاهاى اطراف منطقه نايين در استان

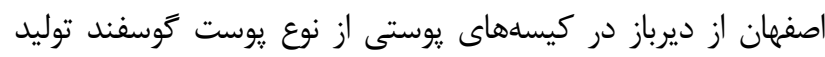

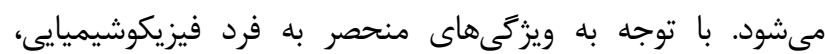
ميكروبيولوزيكى و نيز عدم وجود نمك در اين محصول لبنى، مى بوتوان

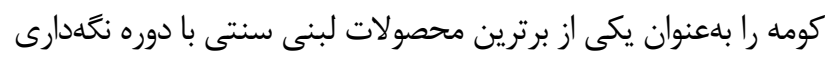

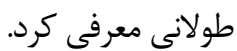

Sharifi

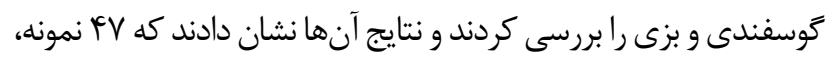

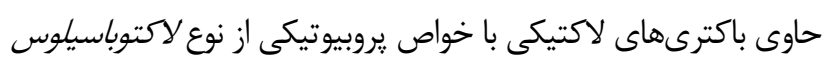
لاكتيس، لاكتوباسيلوس برويس و لاكتوباسيلوس فرمنتوم بود (9). Famouri لاكتوباسيلوس بلانتاروم و لاكتوباسيلوس برويس ايزوله شده از • • انمونه

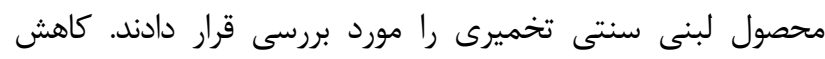
كلسترول سرم خون و كاهش مسموميت فلزات سنخين، از نتايج مطلوب

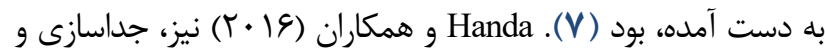
شناسايى باكترىهاى اسيدلاكتيك، از ب نمونه نوشيدنى تخميرى سنتى

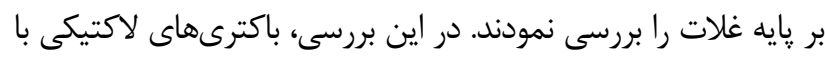

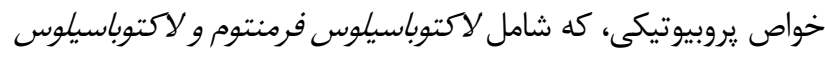
/سيدوفيلوس بودند، از اين نوشيدنى جداسازى و شناسايى شدند و

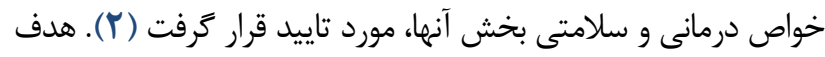

${ }^{1}$ Kwomeh 
رشد، بررسى گرديد. ابتدا كشت فعال از باكترىهاى يروبيوتيكى، تهيه كرديد. سيس، از محيط كشت MRS Agar 1 دريسئ درصد استريل، به مقدار

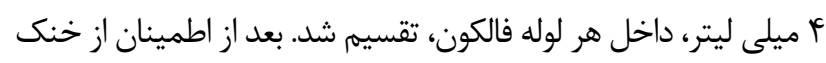
شدن محيط كشت، .ا ماكروليتر از كشت تازه و فعال باكترى يروبيوتيكى، داخل هر لوله فالكون تلقيح گرديد و به خوبى مخلوط شد.

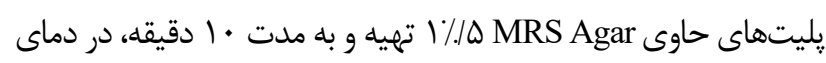
اتاق، قرار داده شدند تا با محيط هم دما گردند. سيس، محيط كشت

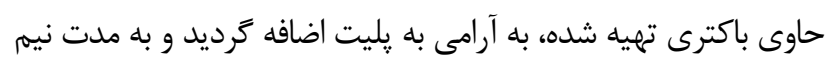

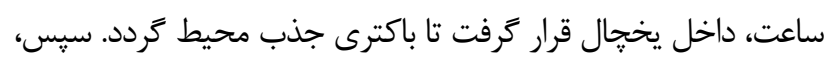

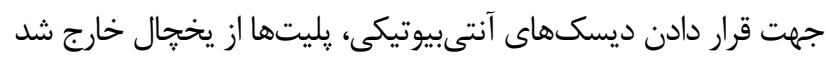

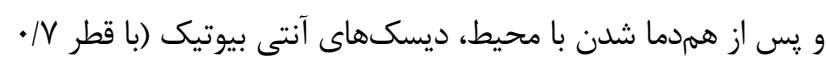

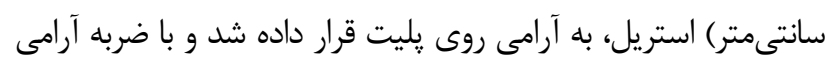
روى محيط كشت تثبيت گرديد و به مدت · r دقيقه، داخل يخجال

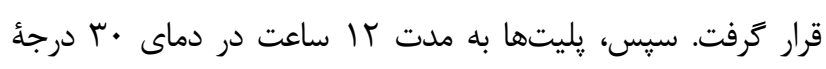

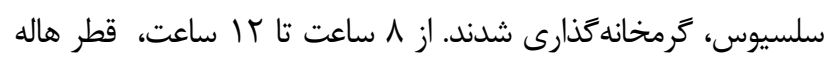
عدم رشد در اطراف ديسكها، مرتبا بررسى شد و قطر هاله نهايى، با

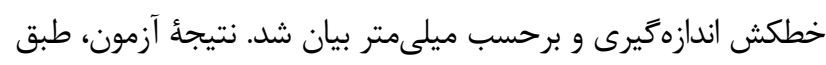

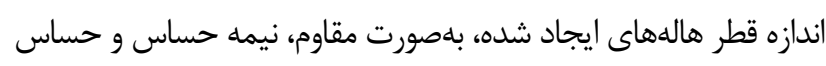

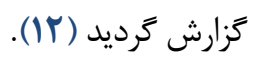

\section{آزمون كاهش كلسترول}

براى بررسى توانايى هيدروليز كلسترول توسط ميكرواركانيسمهاى مورد مطالعه در محيط كشت حاوى كلسترول اتزالات، ابتدا ك/.

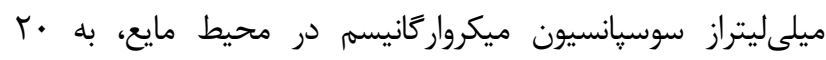

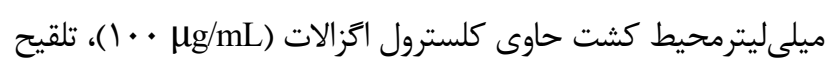
شد و در rV

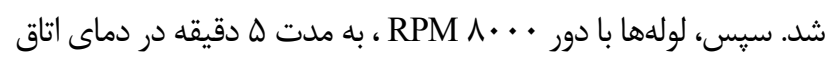
سانتريفوز شدند. ه/ • ميلىليتر از مايع رويى به لوله شيشهاى منتقل و

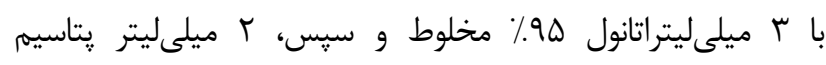

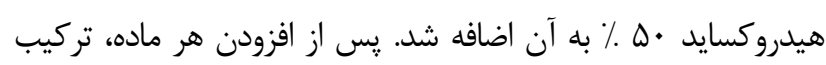

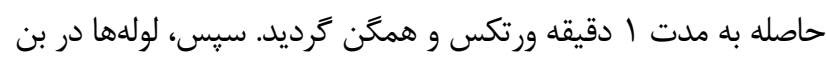

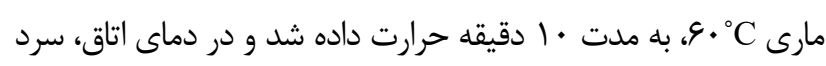

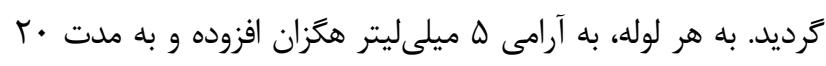
ثانيه ورتكس گرديد و به آنها س ميلىليترآب مقطر افزوده و مجدد به به له

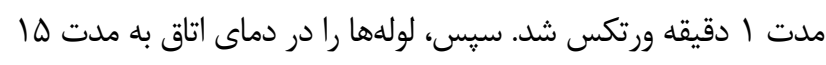
دقيقه و يا تا زمانى كه تفكيك كامل فاز (فاز آبى و فاز آلى) انجام شود،

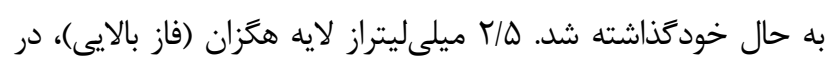
لوله تميز ريخته شد و هكزان، در دماى

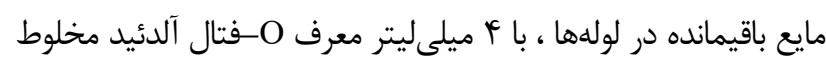

تعداد اوليه بيان شد. بررسى مقاومت و ميزان كاهش رشد ميكرواركانيسم در حضور نمكهاى صفراوى (بايل اتزالات) با غلظت

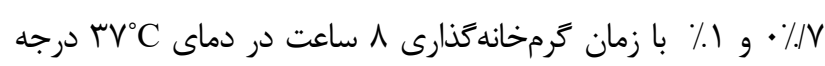
Fرمخانه، بررسى شد. بررسى مقاومت ميكروار كانيسمها در شرايط معده

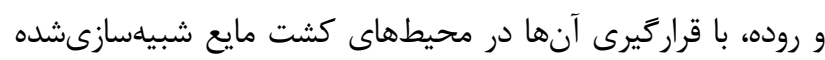

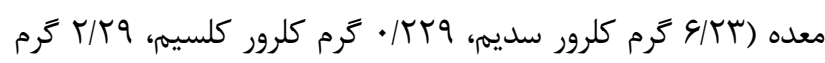

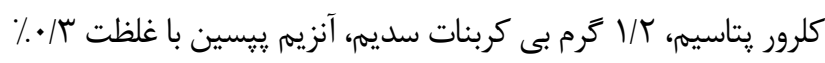

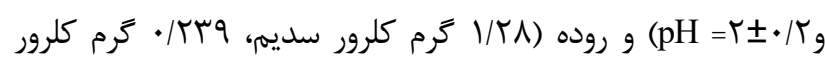

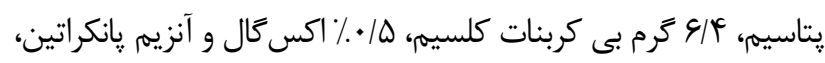

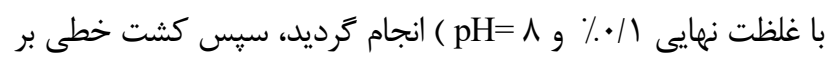
روى محيط كشت آكاردار انجام شد و در نهايت، بعد از گرمخانه گذارى در دما rV

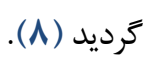

\section{شناسايى باكترىهاى اسيدى ساز}

توليد اسيد توسط ميكرواركانيسمها در محيط كشت، از طايسي ساريق بررسى كاهش pH محيط، بعد از ب ساعت گرمخانه كذارى در دماى بروسى HV انجام شد و باكترىهايى كه نسبت به pHC

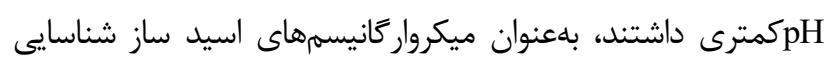

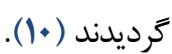

\section{بررسى فعاليت ضد ميكروبى}

بررسى توانايى جدايههاى مورد نظر در توليد تركيبات ضد

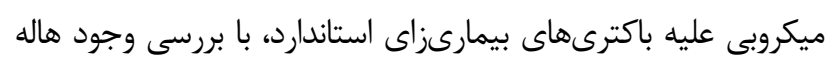

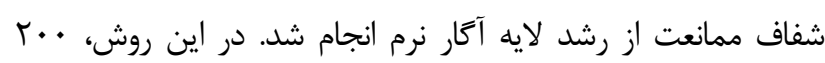

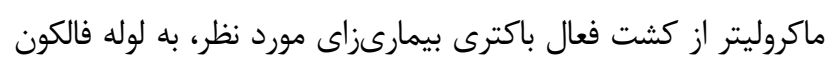

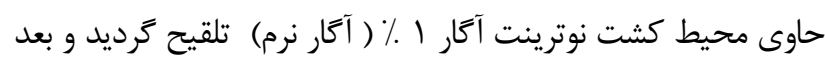

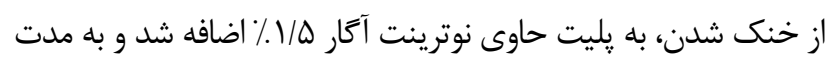

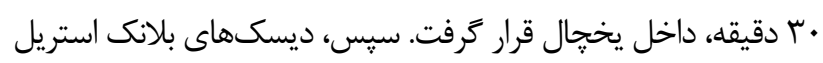

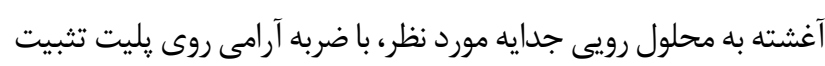

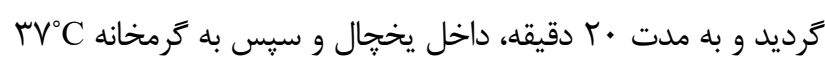

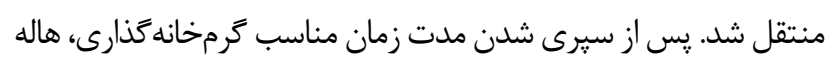
ايجاد شده، با خط كش ميلى مترى اندازهيرى شد. وجود هاله عدم رشد، بلعنوان اثر ضد ميكروبى عليه ميكروارگانيسم بيمارى زاى مورد ادعا

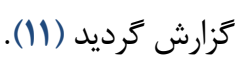

\section{بررسى مقاومت آنتى بيوتيكى}

بررسى حساسيت يا مقاومت باكترىهاى يروبيوتيكى در مقابل

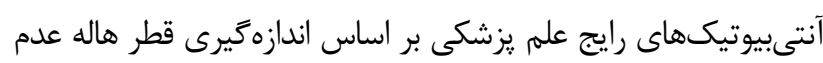


تحليل گرديد. از نرم افزار Excel نسخه • • • براى رسم نمودارها

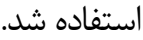

\section{يافتهها}

\section{مقاومت به نمكهاى صفر اوى و اسيد}

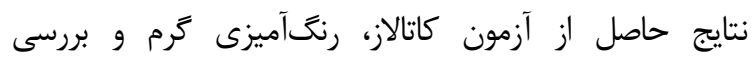

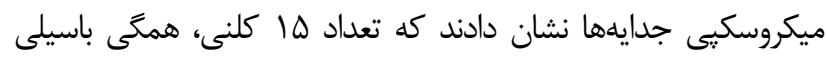
شكل، گرممثبت و كاتالاز منفى بوده كه براى بررسى آزمايشهاى داى يروبيوتيكى انتخاب و به صورت كدهاى S1 الى S15 كدكذارى شدند.

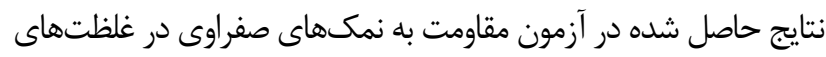

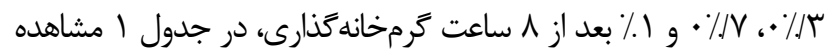

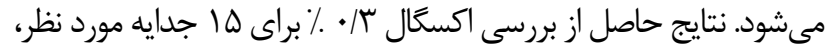

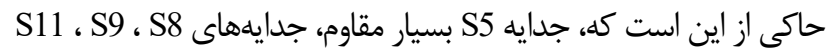

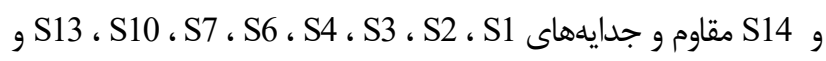

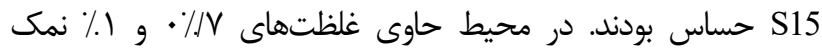

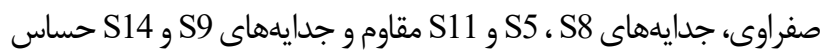

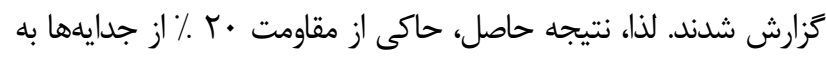

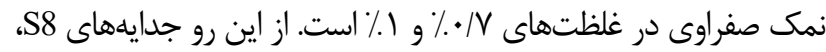
S5 و S11 بهعنوان جدايههاى مقاوم به صفرا، شناخته شدند.

آزمايش مقاومت به اسيد نشان داد كه جدايههاى S15، S14،

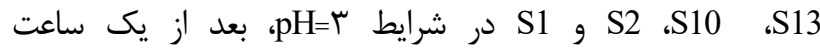
كرمخانه گذارى در دماى

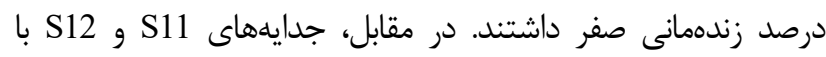

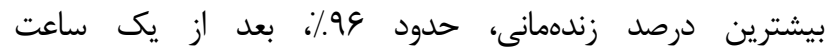

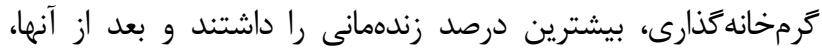

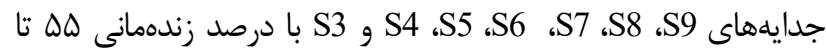

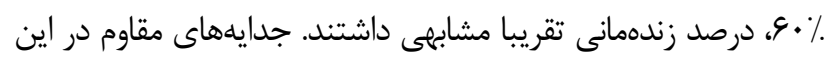

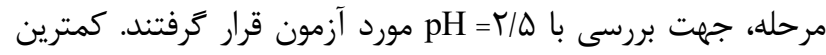

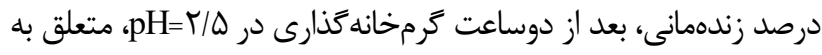

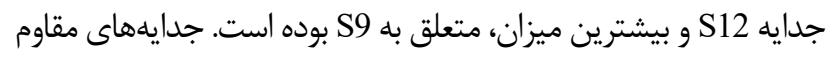

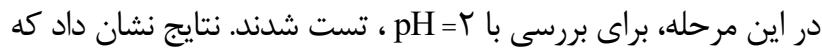
مقاومترين باكترىها به pH اسيدى جدايههاى S11، S7 و S5 بودند.
شد و در دماى اتاق به مدت • • دقيقه نكَهدارى شد و سيس،

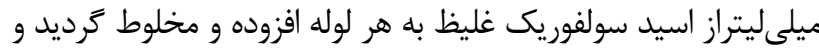

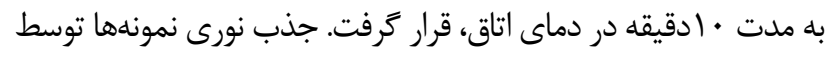
اسيكتروفتومتر در طول موج • •ه نانومتر در مقابل بلانك قرائت كرديد

\section{آزمون فعاليت هيدرولازى نمك صفراوى}

بررسى هاله يا رسوب دزوكسى كوليكى اسيد، در اطراف كلنىها در محيط كشت حاوى نمك سديم اسيدهاى صفراوى بررسى كرديد. • ا ميكروليتر از سوسيانسيون ميكروار كانيسم را روى سطح يليت حاوى

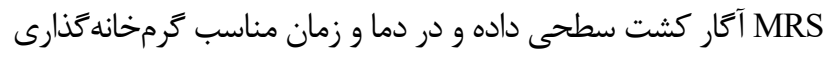
شدند. در صورت فعاليت هيدرولازى، رسوب سفيد و هالههاى يراكنده در اطراف كلنىها به وضوح قابل مشاهده است. در صورت عدم مشاهده

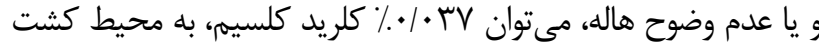
نمونه، اضافه كرد و از ديسكهاى بلانكى آغشته به • •ا ماكروليتر سوسيانسيون باكترى، بر روى سطح يليت استفاده كرد. هاله، به صورت رسوب سفيد در اطراف ديسك، نشان از هيدروليز نمك صفراوى، توسط براط

باكترى مورد نظر را دارد (F) (1).

\section{شناسايى جدايههاى انتخاب شده از آزمونهاى يروبيوتيكى}

هفت جدايهاى كه در آزمونهاى يروبيوتيكى فوق برترى نسبى

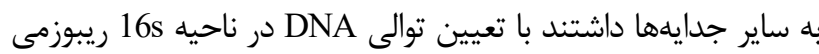

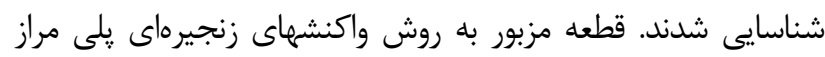
(PCR) تكثير شد. از يرايمر (Corbett Life Science Pty. Ltd., Australia) 5'GAG AGT TTG ATC CTG GCT CAG تمومى با توالى ريشرو '3 و يسرو '5'GAA AGG AGG TGA TCC AGC CG براى تكثير قطعه مورد نظر استفاده كرديد (ها). مراحل واكنش بصورت زير دنبال

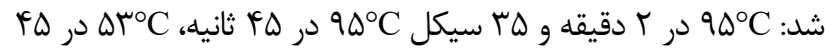
ثانيه، Vr واكنش روى زل آكاروز ^/• ٪ الكتروفورز شد و قطعه از زل استخراج

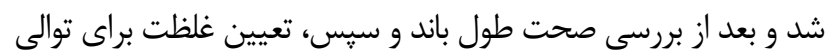
يابى، به شركت Microsynth سوئيس، ارسال شد.

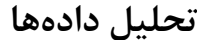

دادههاى حاصل از آزمايشهاى در اين مطالعه، در قالب طرح

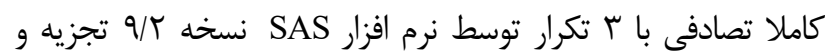




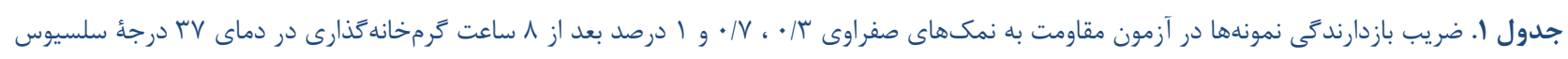

\begin{tabular}{|c|c|c|c|c|c|c|}
\hline نتيجهُ نهايى & ضريب بازدارندَى & نتيجةُ نهايى & 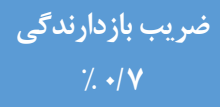 & نتيجةُ نهايى & ضريب بازدارندكى & كد باكترى \\
\hline- & - & - & - & حساس & 1 & S1 \\
\hline- & - & - & - & حساس &.$/ 91$ & $\mathbf{S 2}$ \\
\hline- & - & - & - & حساس & 1 & S3 \\
\hline- & - & - & - & حساس & 1 & S4 \\
\hline مقاوم &.$/ 1 F$ & مقاوم &.$/ 49$ & مقاومت بالا & .119 & S5 \\
\hline- & - & - & - & حساس & 1 & S6 \\
\hline- & - & - & - & حساس & $\cdot / A F$ & S7 \\
\hline مقاوم & $\cdot / r \Lambda$ & مقاوم & $\cdot / 49$ & مقاوم & $\cdot / \mu 1$ & S8 \\
\hline حساس & $\cdot / V F$ & حساس &.$/ 91$ & مقاوم & $\cdot / \pi V$ & S9 \\
\hline- & - & - & - & حساس & 1 & S10 \\
\hline مقاوم & . & مقاوم &.$/ T F$ & مقاوم & . k & S11 \\
\hline- & - & - & - & حساس & $\cdot / \wedge \Delta$ & S12 \\
\hline- & - & - & - & حساس & . & S13 \\
\hline حساس & 1 & حساس & .194 & مقاوم & $\cdot / Y F$ & S14 \\
\hline- & - & - & - & حساس & 1 & S15 \\
\hline
\end{tabular}

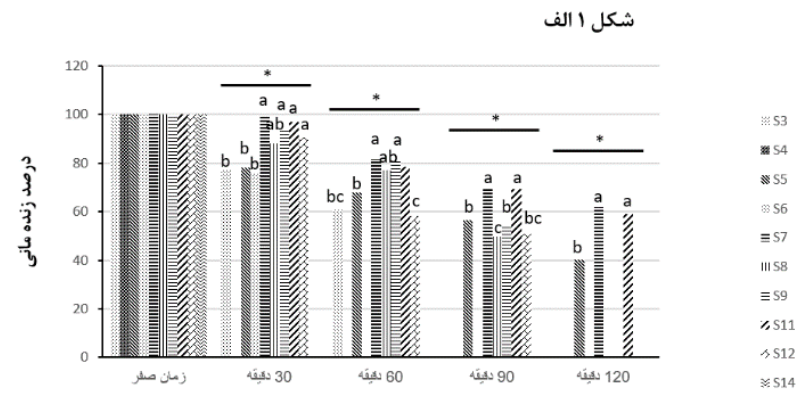

زمان بر حسب دقيقه

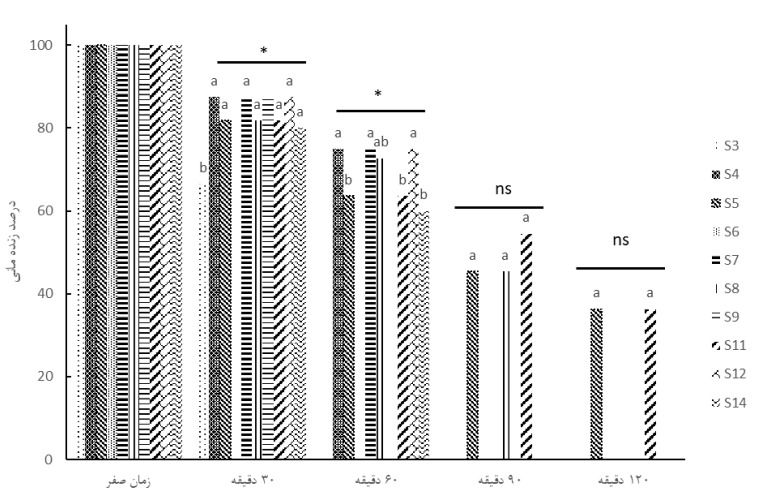

شكلا. درصد زندهمانى نمونهها در شرايط شبيهسازىشده شيره معده (الف) و شيره

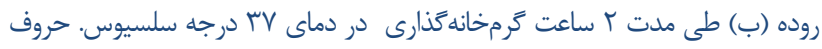

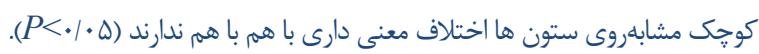

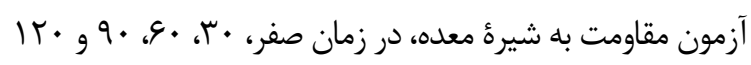
دقيقه، بررسى شد (شكل الف). در اين آزمون، منتخبهاى آزمون

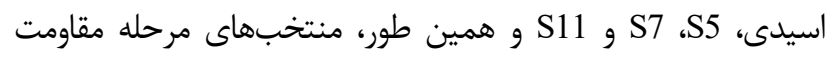
صفراوى، S5، S8 و S11 مورد آزمون قرار گرفتند. البته S14 نيز به دليل

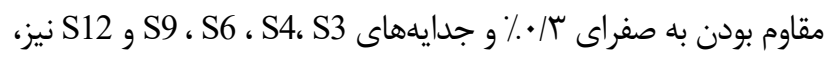
به دليل مقاومت به با بر ، در اين آزمون، مورد بررسى قرار گرفتند.

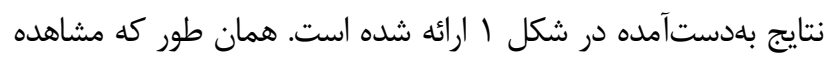
مىشود، جدايههاى S4، S14 و S6 كمترين مقاومت، نسبت به شرايط

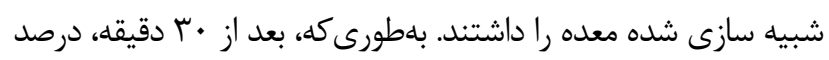

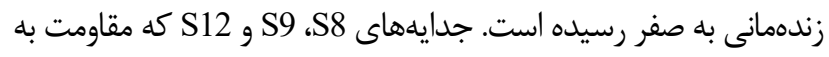

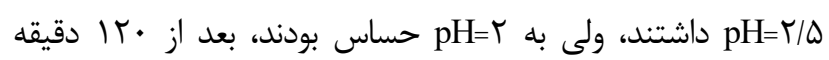

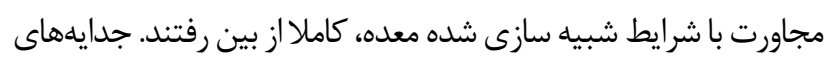

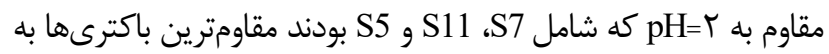
شرايط شبيهسازىشده معده، بعد از r ساعت گرمخانه مذارى نيز بودند ولى جدايه هاى S7 و S11 بهطور معنى دارى زندهمانى بالاتر از S5 بودند

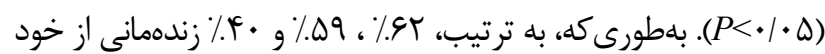
نشان دادند. 
زندهمانى، قادر به تحمل شرايط شبيه سازى شده روده بوده ولى تفاوت

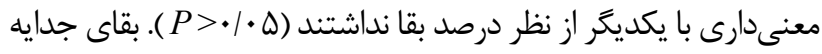

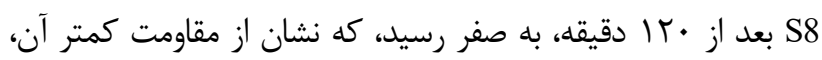

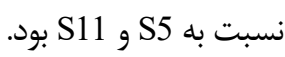

نتايج آزمون توانايى كاهش pH محيط، در جدول ك، قابل مشاهده

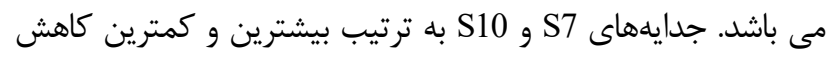

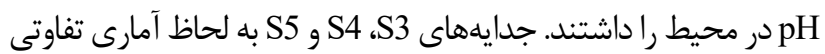

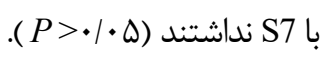

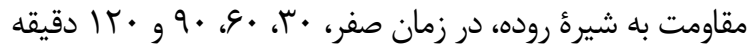
بررسى شد (شكل اب). همانطوركه مشاهده مىشود، جدايه

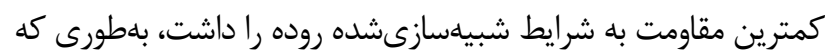

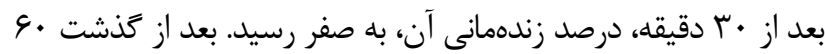
دقيقه، درصد زندهمانى جدايههاى S3 و S9 به صفر رسيد. در اين

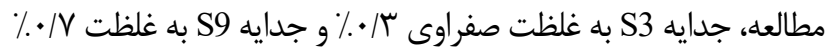

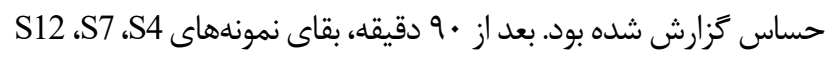
و S14 به صفر رسيد، كه همگى به جز S14 به صفراى س/• بودند و S14 نيز، به صفراى V/ • ٪ حساس ززارش شده بود. در نهايت،

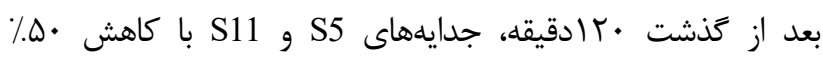
جدول r. درصدكاهش pH محيط توسط ايزوله هاى باكتريايى از محصول لبنى سنتى نائين بعد از TH ساعت كرمخانه كذارى در دماى VY درجه سلسيوس

\begin{tabular}{|c|c|c|c|}
\hline ر رتبه بندى & درصد كاهش pH & pH نهايى pH & كد باكترى \\
\hline ז & NN de & $\Delta / \Phi \mathrm{V}$ & S1 \\
\hline 11 & $19 / 9^{c d}$ & $4 / 91$ & S2 \\
\hline r & $|f| / c^{a b}$ & r & S3 \\
\hline$\Delta$ & $\mathrm{rq} / \mathrm{r}^{\mathrm{ab}}$ & $r / V \wedge$ & S4 \\
\hline f & $r \cdot / q^{a b}$ & $r / 9 V$ & S5 \\
\hline$\wedge$ & $\operatorname{bcd}_{\Gamma \varepsilon}$ & $\varphi / \varphi$. & S6 \\
\hline 1 & ${ }^{\mathrm{a}} \Delta \mathrm{V}$ & $r / 9 V$ & S7 \\
\hline if & $\mathrm{de}_{\text {g/ }}$ & $\Delta / \Lambda \mu$ & S8 \\
\hline$\checkmark$ & $b^{b} r Y / s$ & $4 / 19$ & S9 \\
\hline 10 & $e^{e} / \Delta$ & $\Delta / 9 F$ & S10 \\
\hline r & $b_{F} \Delta / \mathcal{F}$ & 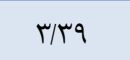 & S11 \\
\hline ir & $\mathrm{d}_{19 \mid \Lambda}$ & $\Delta / I V$ & S12 \\
\hline \& & $b^{2} \mathrm{~V} / \mathrm{l}$ & ए/१1 & S13 \\
\hline 9 & bcd & $F / V \Lambda$ & S14 \\
\hline 1. & $\operatorname{bcd}_{\Gamma} \backslash / \Gamma$ & r/^9 & S15 \\
\hline & $\cdot \cdot \cdot 1$ & & P P P \\
\hline & $r / r r$ & \multicolumn{2}{|c|}{ ميانتين اشتباه استاندارد } \\
\hline
\end{tabular}

حروف كوجى مشابهروى ستون ها اختلاف معنى دارى با هم با هم ندارند (ه • •>P).

\section{فعاليت ضد ميكروبى}

معنى دارى با ساير جدايdها در مهار اين ياتوزن نشان دادند (ه •/•>P).

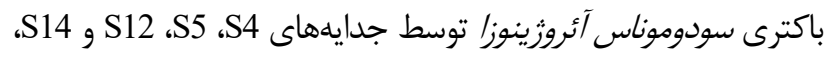

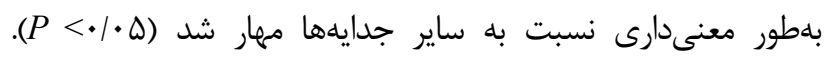

نتايج آزمون فعاليت ضد ميكروبى در جدول ب قابل مشاهده است. بهترين خاصيت ضدميكروبى و به عبارتى، بهترين ززينه براى مهار باكترى سالمونلا تيفىموريوم، جدايههاى S9 و S4 بودند كه تفاوت بهرين 
در نهايت، مخمر كانديد/ آلبيكنس توسط جدايههاى S3 و S14 بهاطور

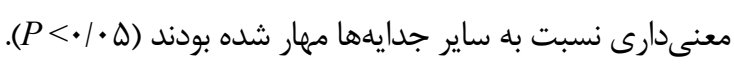

جدايههاىS3، S6 و S8 باكترى /شرشياكلى را بلهور معنى دارى مهار

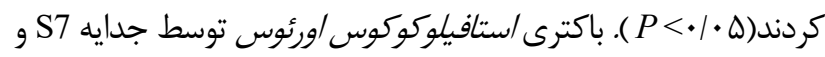

جدول س. فعاليت ضد ميكروبى و رتبهبندى ايزولهها بر حسب قطر هاله (ميلىمتر) در مقابل باكترى هاى بيمارى زا

\begin{tabular}{|c|c|c|c|c|c|c|c|c|c|c|}
\hline \multicolumn{2}{|c|}{$\begin{array}{l}\text { Candida } \\
\text { albicans }\end{array}$} & \multicolumn{2}{|c|}{$\begin{array}{c}\text { Pseudomonas } \\
\text { aeruginosa }\end{array}$} & \multicolumn{2}{|c|}{$\begin{array}{c}\text { Staphylococcus } \\
\text { aureus }\end{array}$} & \multicolumn{2}{|c|}{ Escherichia coli } & \multicolumn{2}{|c|}{$\begin{array}{l}\text { Salmonella } \\
\text { typhimurium }\end{array}$} & \multirow{2}{*}{ باكترى كد } \\
\hline هالد & ر رتبهبند & قطر هالد & ر رتبدبندى & قطر هاله & رتبهبندى & هاله & ر رتبدبند & قطر هاله & ر رتبدبندى & \\
\hline a & r & $a b / 9 / \Delta$ & $\Delta$ & $a b_{\text {IV }}$ & 4 & $a_{\Gamma T / \Delta}$ & $r$ & $\mathrm{bc}_{\mathrm{ir}}$ & $\wedge$ & S3 \\
\hline $\mathrm{b}_{\mathrm{V} / \mathrm{\Delta}}$ & 1. & aT $1 / \Delta$ & r & $a_{19}$ & r & $b c_{q}$ & 1. & aT $/ / Q$ & r & S4 \\
\hline$a b_{1} / V / \Delta$ & 9 & atr & r & $c_{q}$ & $\wedge$ & abc a a a & $\wedge$ & ${ }^{b c} 10$ & $\Delta$ & S5 \\
\hline $\mathrm{b}_{\curlywedge}$ & 9 & ${ }^{a b}{ }_{I N V D}$ & 4 & bc/r & $\checkmark$ & aTI/Va & r & ${ }^{\mathrm{d}} N \Delta$ & 1. & S6 \\
\hline abiNVD & r & $a{ }^{a} / \Lambda$ & $\wedge$ & atr & 1 & $\begin{array}{c}{ }^{a b} \mid r / r \Delta \\
c\end{array}$ & 9 & $\mathrm{bc}, f / T a$ & 9 & S7 \\
\hline${ }^{a b}$ IV & v & $a b_{1} / f$ & 9 & ${ }^{c} \wedge$ & 1. & ${ }^{a} \Gamma \Delta$ & 1 & ${ }^{a b}{ }_{N} N \Delta$ & f & S8 \\
\hline${ }^{a b}{ }_{I N D}$ & $\Delta$ & ${ }^{a b}{ }_{1 N A}$ & v & $a b / q / \Delta$ & r & ${ }^{a b}{ }_{1 \Lambda}$ & 4 & ${ }^{a} T r / b$ & 1 & S9 \\
\hline$b_{1 f}$ & $\wedge$ & $\mathrm{V} / \mathrm{\Delta}$ & 11 & ${ }^{\mathrm{C} V / \Delta}$ & 11 & ${ }^{c} \& / 0$ & 11 & $\mathrm{bc}_{1}$. & 9 & S11 \\
\hline$b_{V}$ & 11 & ${ }^{a} \varphi_{\Delta}$ & 1 & $\mathrm{ab}_{1} \mathrm{ND}$ & $\Delta$ & $a b_{19}$ & $\Delta$ & $a b_{19}$ & r & S12 \\
\hline${ }^{a} T / d$ & 1 & ${ }^{a} T Y / d$ & $r$ & ${ }^{\mathrm{c} N / \Delta}$ & 9 & $\mathrm{abc} / \mathrm{V} / \mathrm{a}$ & v & ${ }^{\mathrm{Cd}} V / T \Delta$ & 11 & S14 \\
\hline \multicolumn{2}{|c|}{ Vancomycin } & \multicolumn{2}{|c|}{ Erythromycin } & \multicolumn{2}{|c|}{ Stereptomycin } & \multicolumn{2}{|c|}{ Amoxicilin } & \multicolumn{2}{|c|}{ Cefalexin } & آنت المتكS \\
\hline$a_{19}$ & r & $\mathrm{bc} / 1 / T \omega$ & 1. & abr. & r & $\mathrm{ab}_{\mathrm{T}}$. & r & ${ }^{b c} / T / \Delta$ & v & المى بيويك \\
\hline$\cdot \cdot r \Lambda$ & & .1 .49 & & $\cdot / \cdot{ }_{4} \Delta$ & & $\cdot|\cdots|$ & & $\cdot|\cdots|$ & & ارزش P \\
\hline r/ठ१ & & $r / 919$ & & R/TMI & & $r / A r \mid$ & & $\Gamma / \Gamma \Delta 1$ & & ميانكين اشتباه \\
\hline
\end{tabular}

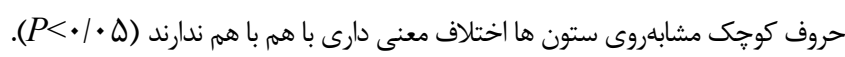

\section{كاهش كلسترول}

نتايج حاصل شده از آزمون كاهش كلسترول توسط جدايههاى

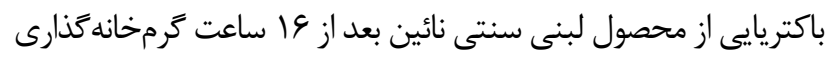

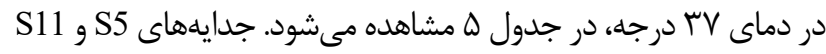

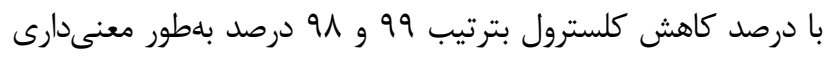

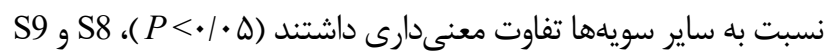

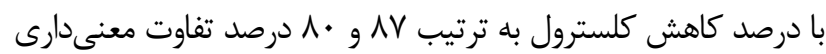

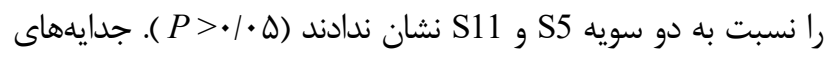
S5 S11 و S8 از مقاومت خوبى در برابر نمكهاى صفراوى برخوردار

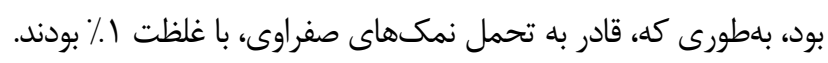

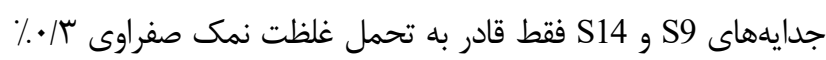

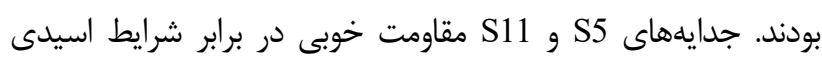
داشته، بهطورى كه، قادر به تحمل شرايط اسيدى، با ب=pH بودند. جدايه

\section{مقاومت آنتى بيوتيكى}

نتايج مقاومت آنتى بيوتيكى جدايههاى باكتريايى از محصول لبنى نئى

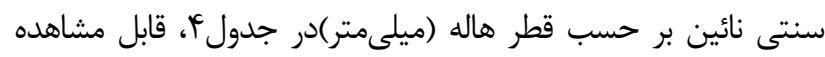

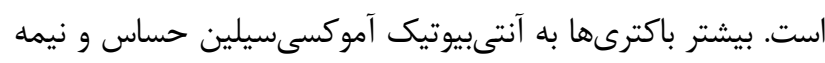

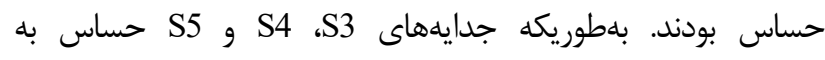

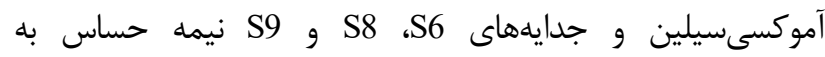

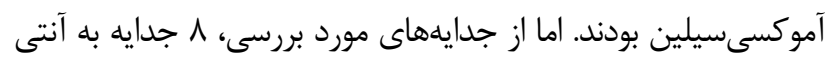

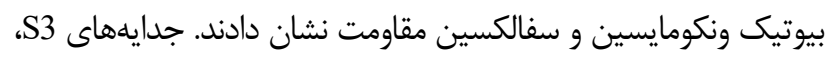

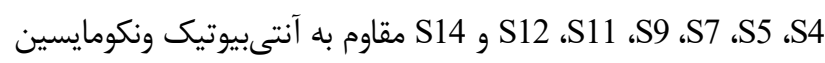

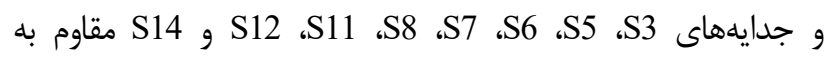
آنتىبيوتيك سفالكسين بودند. 
كلسترول را نشان دادند. جدايه S12 كمترين اثر را در كاهش درصد

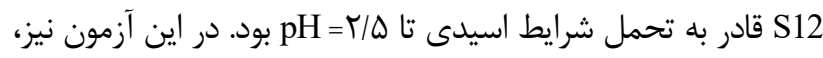

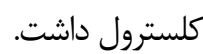

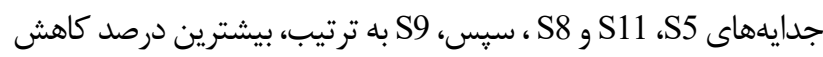

جدول f. مقاومت آنتىبيوتيكى ايزولههاى باكتريايى از محصول لبنى سنتى نائين بر حسب قطر هاله (ميلىمتر)

\begin{tabular}{|c|c|c|c|c|c|c|c|}
\hline $\begin{array}{c}\text { FM300 } \\
\text { Nitrofurantoin }\end{array}$ & $\begin{array}{c}\text { CN30 } \\
\text { Cefalexin }\end{array}$ & $\begin{array}{c}\text { V30 } \\
\text { Vancomycin }\end{array}$ & $\begin{array}{c}\mathbf{S 1 0} \\
\text { Stereptomycin }\end{array}$ & $\begin{array}{c}\text { C30 } \\
\text { Chloramphenicol }\end{array}$ & $\begin{array}{c}\text { AMX 25 } \\
\text { Amoxicilin }\end{array}$ & $\begin{array}{c}\text { E15 } \\
\text { Erythromycin }\end{array}$ & كد جدايه \\
\hline نيمه حساس & مقاوم & مقاوم & نيمه حساس & مقاوم & حساس & مقاوم م & S3 \\
\hline 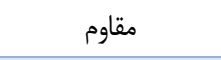 & حساس & 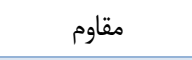 & 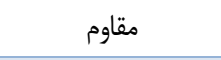 & حساس & حساس & حساس & S4 \\
\hline 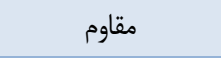 & 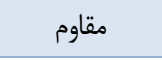 & 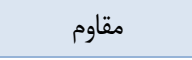 & 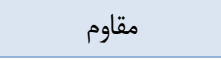 & 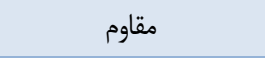 & حساس & مقاوم مق & S5 \\
\hline 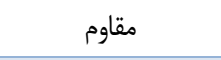 & 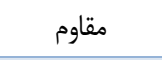 & حساس & 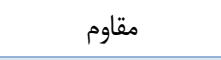 & نيمه حساس & نيمه حساس & 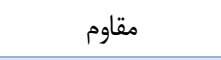 & S6 \\
\hline 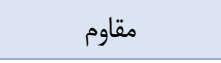 & 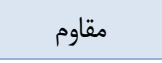 & 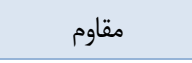 & 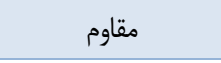 & مقاوم & مقاوم & 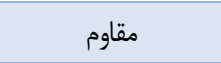 & S7 \\
\hline حساس & 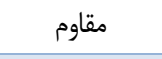 & نيمه حساس & حساس & مقاوم مق & نيمه حساس & 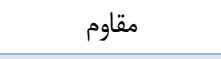 & S8 \\
\hline 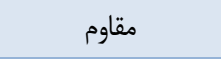 & نيمه حساس & 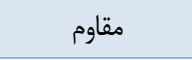 & 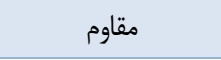 & نيمه حساس & نيمه حساس & 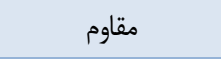 & S9 \\
\hline- & 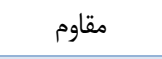 & مقاوم مق & مقاوم مق & 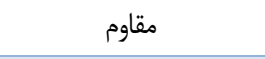 & 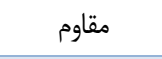 & حساس & S11 \\
\hline حساس & 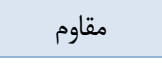 & 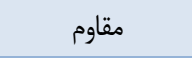 & حساس & 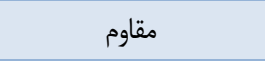 & 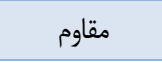 & 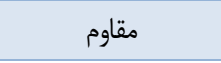 & S12 \\
\hline 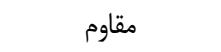 & 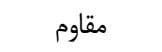 & 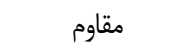 & 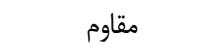 & 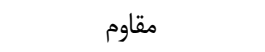 & 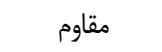 & - & S14 \\
\hline
\end{tabular}

جدول ه. درصد كاهش كلسترول توسط ايزوله هاى باكتريايى از محصول لبنى سنتى نائين بعد از 19 ساعت كرمخانهَّارى در دماى VY درجه سلسيوس

\begin{tabular}{|c|c|c|}
\hline 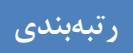 & 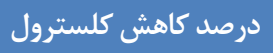 & كد باكترى \\
\hline 1 & $a_{q} q / / f$ & S5 \\
\hline$r$ & ${ }^{a b} \wedge V / r T$ & S8 \\
\hline r & $a^{a b} / / \Delta$. & S9 \\
\hline 1 & aqNit & S11 \\
\hline r & $b_{V} / / r a$ & S12 \\
\hline r & $\mathrm{b}_{\mathrm{V} / Y \mathrm{Y}}$ & S14 \\
\hline &.$/ .14$ & 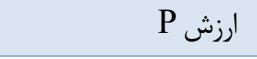 \\
\hline & $\Delta / \Delta V)$ & ميانكين اشتباه استاندارد \\
\hline \multicolumn{3}{|c|}{ 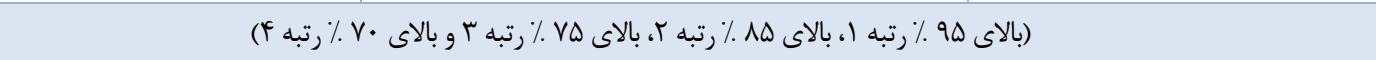 } \\
\hline
\end{tabular}

فوق در آن آزمون، بيشترين درصد كاهش كلسترول را، داشتند. در

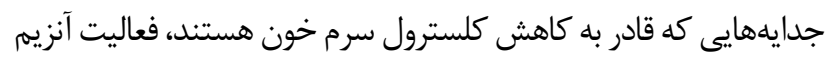

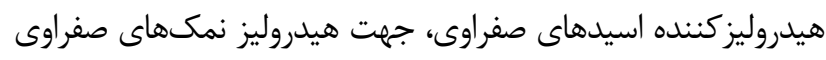
مشاهده شد، بنابراين يك همبستخى بين اين دو صفت پِيشنهاد شدر.

\section{شناسايى مولكولى باكترى هاى ايزوله با خواص بروبيوتيكى}

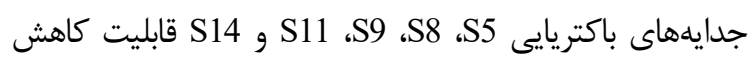

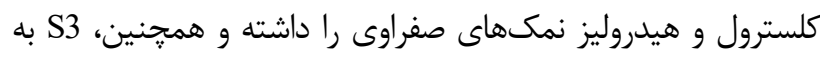

نتايج آزمون فعاليت هيدرولازى نمكهاى صفراوى در جدول 4 قابل مشاهده است. در اين آزمون نيز، مانند روش كاهش كمالئ كلسترول،

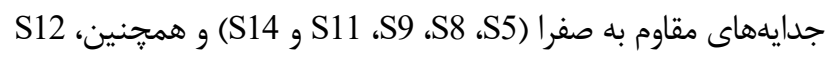

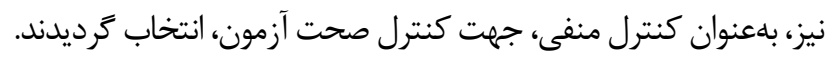

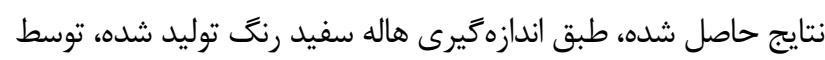

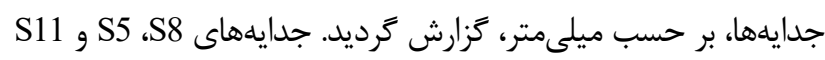

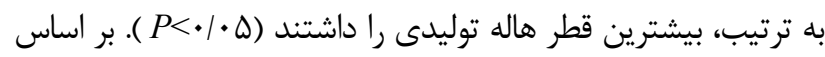

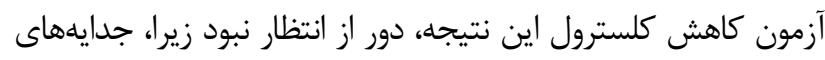


جدايههاى مورد بررسى، در جدول V قابل مشاهده است. بر اين اساس،

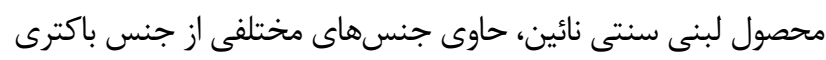

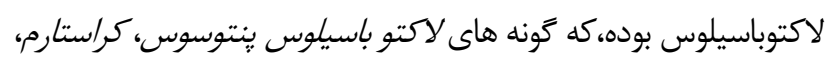
برويس و فرمنتوم، شناسايى كرديدند.
دليل خاصيت ضد ميكروبى بيشتر و S7 به دليل مقاومت زياد به pH و

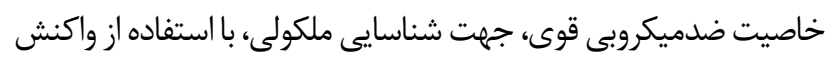

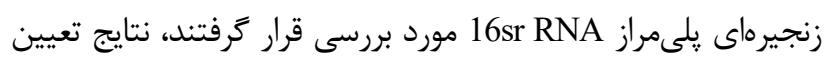
توالى، با توالىهاى موجود در بانكهاى اطلاعات زن (eztaxon) NCBI EzBioCloud's

$$
\text { جدول 9. فعاليت هيدرولازى نمك هاى صفراوى بر حسب قطر هاله توسط ايزولههاى باكتريايى از محصول لبنى سنتى نائين }
$$

\begin{tabular}{|c|c|c|c|}
\hline 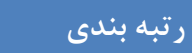 & قوى، ضعيف، متوسط & قطر هاله (mm) & كد باكترى \\
\hline$r$ & قوى & ${ }^{a b} r / a$ & S5 \\
\hline 1 & قوى ق & ac & S8 \\
\hline p & متوسط & ${ }^{b} / / \Delta$ & S9 \\
\hline$r$ & قوى & $\mathrm{ab}_{\mu}$ & S11 \\
\hline 9 & ضعيف & $b_{1 / b}$ & S12 \\
\hline \multirow[t]{3}{*}{$\Delta$} & متوسط & $\mathrm{b}_{T / T \Delta}$ & S14 \\
\hline & &.$/ \cdot r t$ & ارزش p \\
\hline & & $\cdot \mid \Delta V F$ & ميانكَين اشتباه استاندارد \\
\hline
\end{tabular}

جدول V. نتايج بلاست توالى ناحيه 16s ريبوزمى DNA ايزولههاى محصول لبنى سنتى نائين بر اساس بانكهاى اطلاعاتىN gCBtaxon

\begin{tabular}{|c|c|c|c|c|c|c|}
\hline شباهت & جدايه & كونهُ مشخصشده & شباهت & جدايه & $\begin{array}{l}\text { كونهُ مشخصشده در } \\
\text { Taxon }\end{array}$ & كد باكترى \\
\hline $1 .$. & $\begin{array}{c}\text { Strain } \mathrm{H}_{1}, 16 \mathrm{~S} \text { ribosomal } \\
\text { RNA gene }\end{array}$ & $\begin{array}{l}\text { Lactobacillus } \\
\text { Plantarum }\end{array}$ & $1 .$. & $\begin{array}{c}\text { DSM } \\
20314(T)\end{array}$ & Lactobacillus Pentosus & S3 \\
\hline $1 .$. & $\begin{array}{l}\text { Strain B481,16S } \\
\text { ribosomal RNA gene }\end{array}$ & $\begin{array}{l}\text { Lactobacillus } \\
\text { Crustorum }\end{array}$ & १९/१५ & $\begin{array}{c}\text { LMG } \\
23699(\mathrm{~T})\end{array}$ & $\begin{array}{l}\text { Lactobacillus } \\
\text { Crustorum }\end{array}$ & S5 \\
\hline ११/V। & $\begin{array}{l}\text { Strain APBSMLB166,16S } \\
\text { ribosomal RNA gene }\end{array}$ & $\begin{array}{l}\text { Lactobacillus } \\
\text { fermentum }\end{array}$ & १९/ท। & $\begin{array}{l}\text { CECT } \\
562(\mathrm{~T})\end{array}$ & $\begin{array}{l}\text { Lactobacillus } \\
\text { fermentum }\end{array}$ & S7 \\
\hline $1 .$. & $\begin{array}{l}\text { Strain PS7319,16S } \\
\text { ribosomal RNA gene }\end{array}$ & $\begin{array}{l}\text { Lactobacillus } \\
\text { Plantarum }\end{array}$ & १९/१ & $\begin{array}{c}\text { DSM } \\
20314(\mathrm{~T})\end{array}$ & Lactobacillus Pentosus & S8 \\
\hline $99 / \% 4$ & $\begin{array}{l}\text { Strain 10-18 16S } \\
\text { ribosomal RNA gene }\end{array}$ & $\begin{array}{l}\text { Lactobacillus } \\
\text { fermentum }\end{array}$ & $99 /{ }^{4}$ & $\begin{array}{l}\text { CECT } \\
562(\mathrm{~T})\end{array}$ & $\begin{array}{l}\text { Lactobacillus } \\
\text { fermentum }\end{array}$ & S9 \\
\hline $1 .$. & $\begin{array}{l}\text { Strain NOS7311 16S } \\
\text { ribosomal RNA gene }\end{array}$ & $\begin{array}{l}\text { Lactobacillus } \\
\quad \text { brevis }\end{array}$ & $99 / \wedge 9$ & $\begin{array}{c}\text { ATCC } \\
14869(\mathrm{~T})\end{array}$ & Lactobacillus brevis & S11 \\
\hline $1 .$. & $\begin{array}{l}\text { Strain SKB1021 16S } \\
\text { ribosomal RNA gene }\end{array}$ & $\begin{array}{l}\text { Lactobacillus } \\
\quad \text { brevis }\end{array}$ & ११/१ & $\begin{array}{c}\text { ATCC } \\
14869(\mathrm{~T})\end{array}$ & Lactobacillus brevis & S14 \\
\hline
\end{tabular}

بيفيدوباكتريومها نسبت به لاكتوباسيلوسها و همجنين، مقاومت بيشتر جدايههاى لاكتوباسيلوس در شرايط اسيدى، نسبت به /ستريتوكوكوس

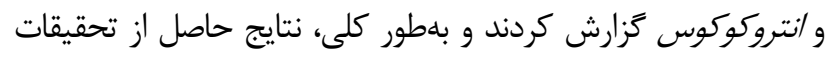

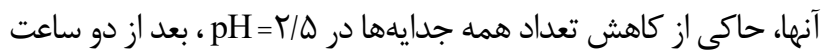

در بررسى مقاومت به شرايط اسيدى، شش جدايه از ها جدايه

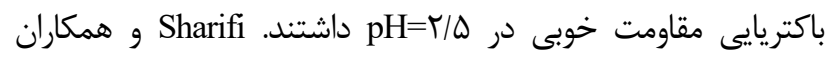
(Y.IV)

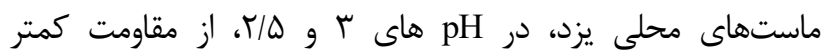


رسيده بود و در pH=r/D نيز، مقاومت نشان نداد و همجنين، تحمل

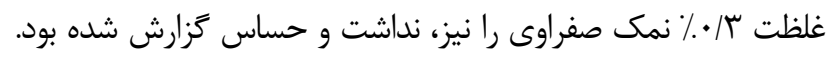

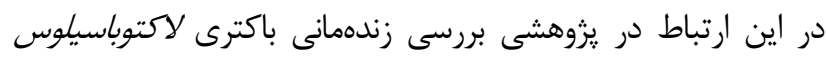
رامنوسوس جى جى، در شرايط شبيهسازىشده روده، نشان دادند كه

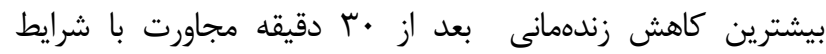

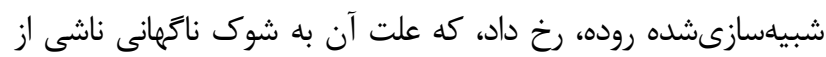
مجاورت باكترى با pH بالا و حضور نمك هاى صفراوى نسبت داده شد داند كه حاكى از حساسيت بيشتر اين باكترى، به شرايط شبيهسازىشده روده است(19).

در بررسى اثرات ضد ميكروبى نتايج نشان داد كه بهترين گزينه براى مهار باكترى سالمونلا تيفىموريوم جدايههاى S9 و S4، باكترى

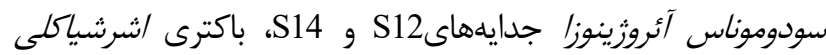
جدايههاى S3 و S8، باكترى /ستافيلوكوكوس /ورئوس جدايههاى S7 و و S9 و در نهايت، مخمر كانديدا آلبيكنس جدايههاى S3 و S14 بود. اثر الثرائ ضد ميكروبى برخى از جدايههاى لاكتوباسيلوس ، تا حدى با كاهش

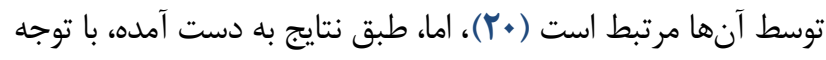
به مكانيسمهاى جدايههاى لاكتوباسيلوس، در اعمال خاصيت ضدميكروبى شايد نتوان همه خواص ضدميكروبى را به كاهش مرتبط دانست بلكه ترشح باكتريوسينها كه تركيبات ضد باكتريايى هاني

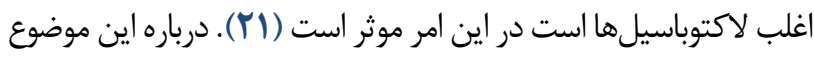

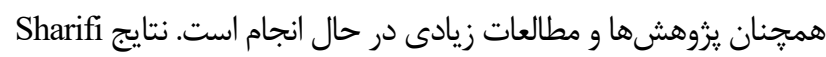
و همكاران (Y IV) در بررسى جدايههاى لاكتوباسيلوس از محصول

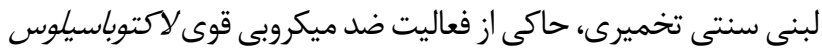

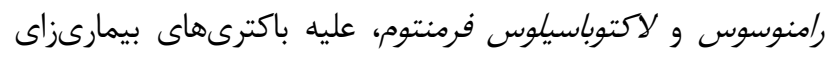
سالمونلا تيفى موريوم، استافيلوكوكوس اورئوس و /شرشياكلى بود(و). در همين راستا در بررسى فعاليت ضدميكروبى ايزولههاى لاكتوباسيلوس

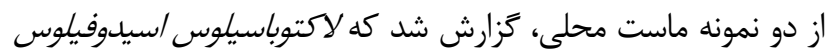

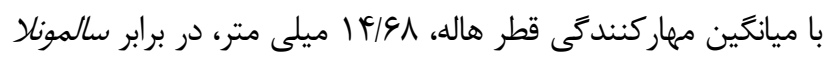

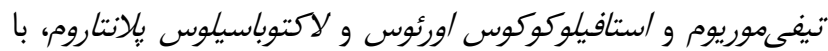

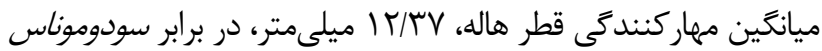

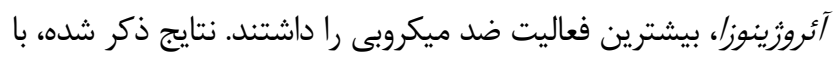
نتايج مطالعه حاضر نيز، مطابقت داشت.

يكى از جنبه هاى مهم قابل بررسى، در زمينه ايمنى استفاده از يروبيوتيكها، مقاومت آنتى بيوتيكى است. اين يتانسيل، خطر ناشى ازئ داز

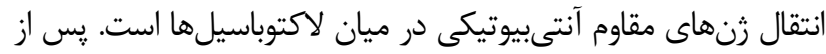

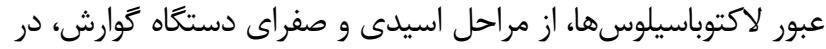
صورتى كه واجد زنهاى مقاومت به آنتىبيوتيك مستقر بر بِاسميد
بوده است. Akabandaو همكاران (T/ •Y) نشان دادند، در شرايط

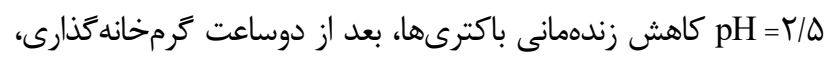
نسبت به يك ساعت، جشمخير است (9) ). مطابق با نتايج مطالعه حاضر، اثر زمان بر كاهش مقاومت و كاهش زندهمانى جدايهها نيز، موثر بوده

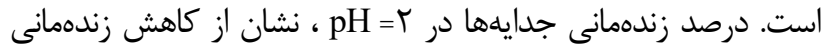

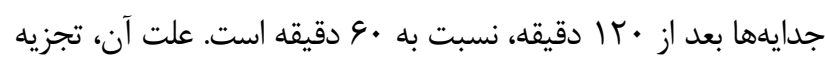
شدن بيشتر ديواره سلول باكترى توسط اسيد، در مدت زمان بيشتر

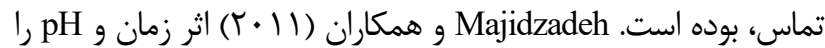
در كاهش فعاليت جدايهها بررسى كرده و نشان دادند، بعد از باساعت

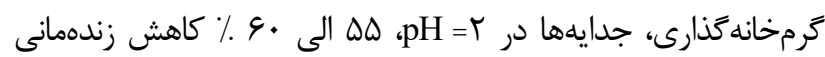
داشتند كه با نتايج اين مطالعه مطابقت دارد (IV). نتيجه حاصل شده در آزمون مقاومت به نمكهاى صفراوى،

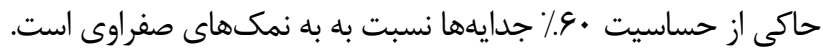

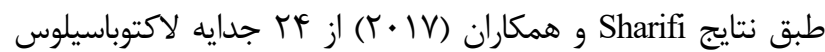

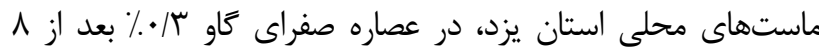
ساعت، • ا جدايه مقاوم، دو جدايه بسيار مقاوم و كا جدايه غير مقاوم

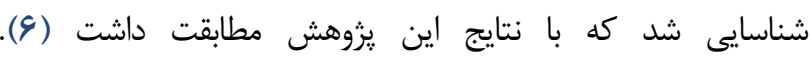
و Hajighasemi

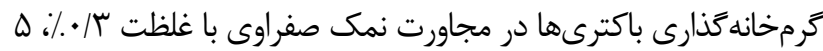

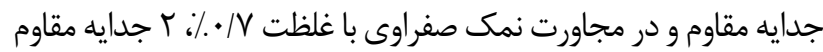

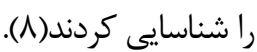
جدايههاى S8، S9 و S12 كه مقاومت به D/ = pH داشتند، ولى

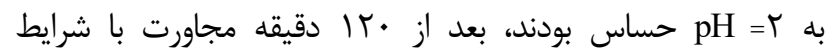

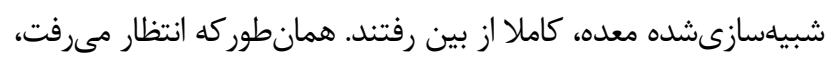
جدايههاى مقاوم به بH=r، به ترتيب، S7، S11 و S5 مقاومترين

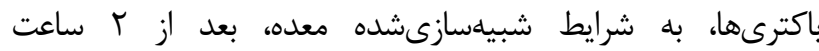

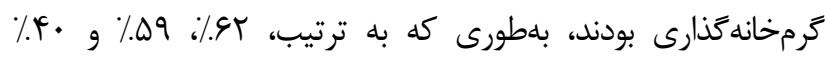

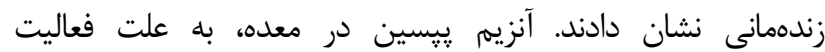
يروتئوليتيك، بر ديواره سلولى باكترى اثر كذاشته و منجر به نابودى دنى دنائي

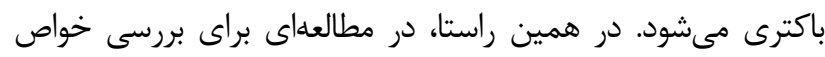

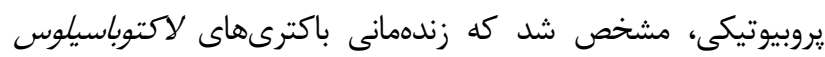

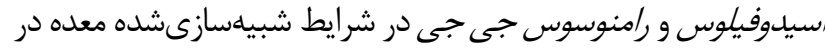
حدود •4 \% كاهش يافت درحالى كه تحت اثر تيمار نمك كامل بـ با بآنزيم

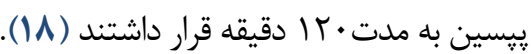
در شرايط شبيهسازىشده روده، جدايه S6 كمترين مقاومت را نشان داد بلطورى كه اين نتيجه قابل انتظار بود زيرا، زندهمانى اين

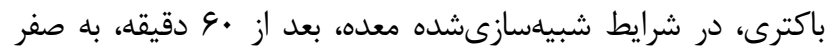


كننده صفراوى، نسبت داده شده كه سبب كاهش 1 تا • ا درصد

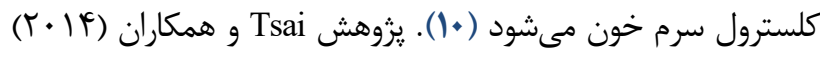

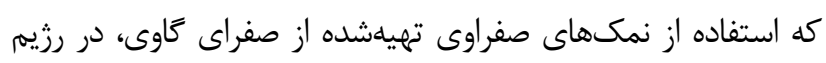

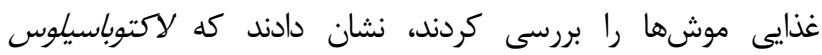
اسيدوفيلوس و لاكتوباسيلوس فرمنتوم، بيشترين كاهش كلسترول سرمى برى را داشتند كه مطابق با نتيجأ اين تحقيق بوده (جدايه لاكتوباسيل فرمنتوم، S8 و علت كاهش كلسترول سرم خونى موشها را، حضور آنزيمهاى (S8) هيدروليزكننده صفراوى، توسط اين جدايههاى لاكتوباسيلوس دانستند

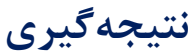

در اين مطالعه نشان داده شد كه كومه داراى يتانسيل زيادى براى

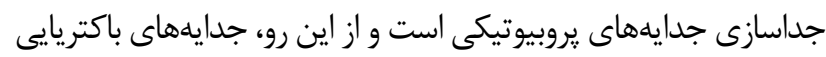

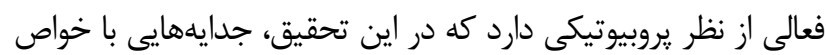
يروبيوتيكى از اين محصول لبنى تخميرى سنتى نائين جداسازى كرديد.

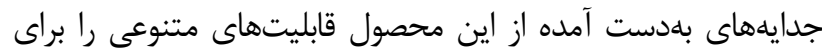

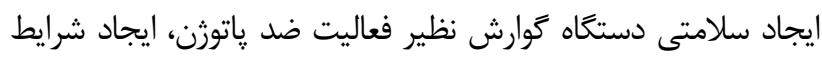
اسيدى و همجنين قابليت تجزيه كلسترول كه در ايجاد تندرستى مصرفكننده موثر است، دارد.

\section{سياسگزارى}

نويسندكان اين مقاله از دانشگاه آزاد اسلامى- واحد نور كه

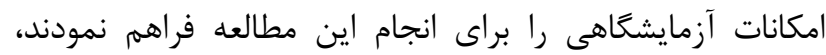

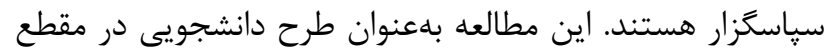

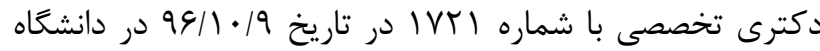
آزاد اسلامى - واحد نور به تصويب رسيده است.

\section{تعارض در منافع}

در انجام اين مطالعه، نويسندكان هيجَّونه تضاد منافعى

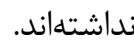

\section{Referance}

1. Bastani P, Akbarzadeh F, Homayouni A, Javadi M, Khalili L. Health Benefits of Probiotic Consumption. In: Garg N, Abdel-Aziz SM, Aeron A, editors. Microbes in Food and Health. Cham: Springer International Publishing; 2016. p. 163-83. [DOI:10.1007/978-3-319-25277-3_9] [PMID] [PMCID]

2. Handa S, Sharma N. In vitro study of probiotic properties of Lactobacillus plantarum F22 isolated from chhang-A traditional fermented beverage of Himachal Pradesh, India. J Genet Eng Biotechnol.
باشد، احتمال انتقال جنين زنهايى، به ساكنين دائمى دستخاه گوارش و

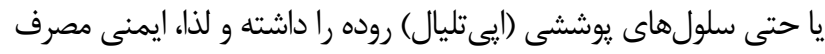

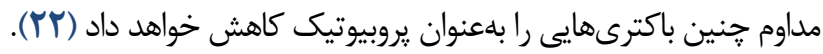
در يزوهشى مقاومت جدايههاى لاكتوباسيلوس جداشده، از ينير محلى ئلى

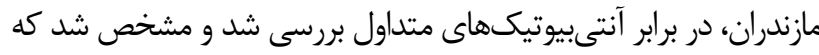
اكثر جدايهها نسبت به آنتىبيوتيك استريتومايسين، ونكومايسين و و جنتامايسين، مقاوم بودند و در برابر آموكسىسيلين حساس و در برابر آنتىبيوتيك نيتروفورانتوئين نيز، نيمه حساس تزارش شدند (ساب). اين نتايج، با نتيجة حاصل از يروهش حاضر، مطابقت داشت.

Tsai به تاثير باكترى لاكتوباسيلوس رامنوسوس و لاكتوباسيلوس بولاريكوس، در كاهش كلسترول سرم خونى رتها، بيى برده و اظهار داشتند كه، جدايه

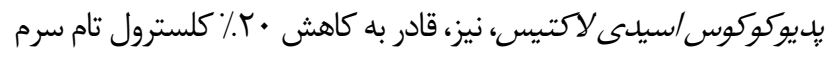

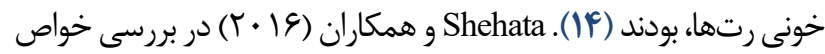

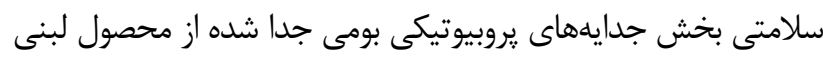

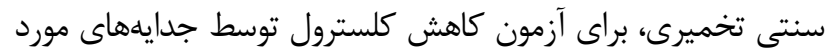

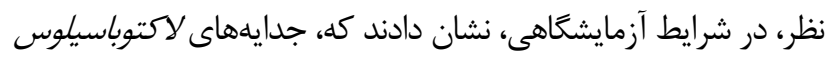

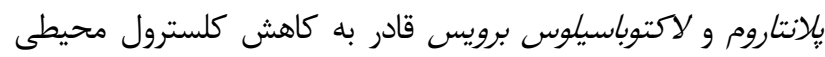

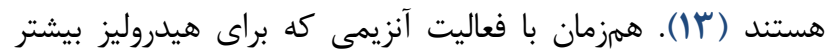
نمك هاى صفراوى بلوسيلة جدايهها صورت مى گيرد، كاهش كلسترول

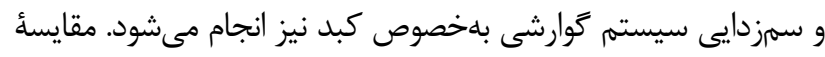

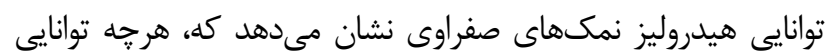
باكترىها در هيدروليز اين نمكها بيشتر باشد، كاهش كلسترول و سمزدايى سيستم كوارشى، بهخصوص كبد، با قابليت بهترى انجام

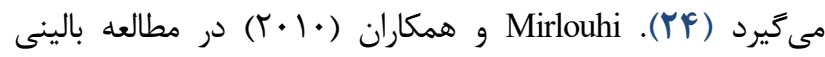

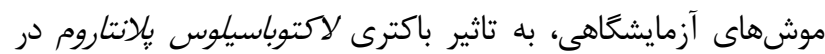
كاهش كلسترول سرم خونى اشاره داشته و يكى از عوامل كاهش بانش

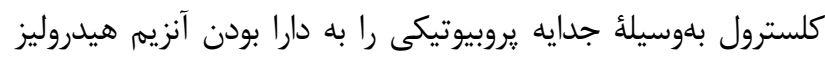

2016;14(1):91-7. [DOI:10.1016/j.jgeb.2016.08.001] [PMID] [PMCID]

3. Jadhav K, Sharma K, Katoch S, Sharma V, Mane B. Probiotics in broiler poultry feeds: A review. J Anim Nutr Physiol. 2015;1:04-16.

4. Barzegari A, Eslami S, Ghabeli E, Omidi Y. Imposition of encapsulated non-indigenous probiotics into intestine may disturb human core microbiome. Front Microbiol. 2014;5:393.

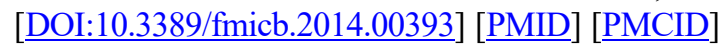


5. Anal AK, Singh H. Recent advances in microencapsulation of probiotics for industrial applications and targeted delivery. Trends Food Sci Technol. 2007;18(5):240-51. [DOI:10.1016/i.tifs.2007.01.004]

6. Sharifi Yazdi MK, Davoodabadi A, Khesht Zarin HR, Tajabadi Ebrahimi M, Soltan Dallal MM. Characterisation and probiotic potential of lactic acid bacteria isolated from Iranian traditional yogurts. Ital J Anim Sci. 2017;16(2):185-8. [DOI:10.1080/1828051X.2016.1222888]

7. Famouri F, Shariat Z, Hashemipour M, Keikha M, Kelishadi R. Effects of probiotics on nonalcoholic fatty liver disease in obese children and adolescents. J Pediatr Gastroenterol Nutr. 2017;64(3):413-7. [DOI:10.1097/MPG.0000000000001422] [PMID]

8. Hajighasemi M, Mojgani N. Identification and Characterization of Probiotic Properties of Indigenous Lactic Acid Bacteria Based on Their Phenotypic and Genotypic Characteristics. Iran J Med Microbiol: Volume. 2016;9(4).

9. Halt J, Krieg N, Sneath P, Stely J, Williums S. Bergey's Manual of systemic Bacteriology. London; 1985 .

10. Mirlouhi M, Soleymanianzad S, Sheykh zeyn aldin M. Identification of Lactobacilli from fecal flora of some Iranian infants. Iran J Pediatr. 2008;18(4):35763.

11. de Valdez GF, Taranto MP. Probiotic Properties of Lactobacilli. Food Microbiology Protocols: Springer; 2001. p. 173-81.

12. Wong A, Ngu DYS, Dan LA, Ooi A, Lim RLH. Detection of antibiotic resistance in probiotics of dietary supplements. Nutr J. 2015;14(1):95. [DOI:10.1186/s12937-015-0084-2] [PMID] [PMCID]

13. Shehata M, El Sohaimy S, El-Sahn MA, Youssef M. Screening of isolated potential probiotic lactic acid bacteria for cholesterol lowering property and bile salt hydrolase activity. Ann Agric Sci. 2016;61(1):65-75. [DOI:10.1016/j.aoas.2016.03.001]

14. Tsai C-C, Lin P-P, Hsieh Y-M, Zhang Z-y, Wu H-C, Huang C-C. Cholesterol-lowering potentials of lactic acid bacteria based on bile-salt hydrolase activity and effect of potent strains on cholesterol metabolism in vitro and in vivo. Sci World J. 2014;2014. [DOI:10.1155/2014/690752] [PMID] [PMCID]

15. Taheri HR, Moravej H, Tabandeh F, Zaghari M, Shivazad M. Screening of lactic acid bacteria toward their selection as a source of chicken probiotic. Poult Sci. 2009;88(8):1586-93. [DOI:10.3382/ps.200900041] [PMID]

16. Akabanda F, Owusu-Kwarteng J, Tano-Debrah K, Glover RL, Nielsen DS, Jespersen L. Taxonomic and molecular characterization of lactic acid bacteria and yeasts in nunu, a Ghanaian fermented milk product. Food microbiol. 2013;34(2):277-83. [DOI:10.1016/j.fm.2012.09.025] [PMID]

17. Majidzadeh Heravi R, Kermanshahi H, Sankian M, Nassiri M, Moussavi AH, Nasiraii LR, et al. Screening of lactobacilli bacteria isolated from gastrointestinal tract of broiler chickens for their use as probiotic. African J Microbiol Res. 2011;5:185868. [DOI:10.5897/AJMR11.416]

18. Esmaeli F, Roozbeh Nasiraie L. Comparision of different treatments of simulated gastrointestinal conditions in probiotic bacterial Lactobacillus acidophilus and Lactobacillus GG in order to achive the most realistic and practical model, : Islamic Azad University, Nour branch; 2014.

19. Boricha AA, Shekh S, Pithva SP, Padma S, Bharatkumar A, Vyas R. In vitro evaluation of probiotic properties of Lactobacillus species of food and human origin. LWT. 2019;106:201-8. [DOI:10.1016/j.lwt.2019.02.021]

20. $\mathrm{Hu} \mathrm{CH}$, Ren LQ, Zhou Y, Ye BC. Characterization of antimicrobial activity of three Lactobacillus plantarum strains isolated from Chinese traditional dairy food. Food Sci Nutr. 2019;7(6):1997-2005.

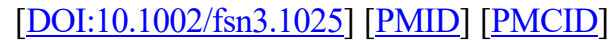

21. Leite AM, Miguel M, Peixoto R, Ruas-Madiedo P, Paschoalin V, Mayo B, et al. Probiotic potential of selected lactic acid bacteria strains isolated from Brazilian kefir grains. J Dairy Sci. 2015;98(6):362232. [DOI:10.3168/jds.2014-9265] [PMID]

22. Kim YI, Poudel BK, Pradhan R, Choi H-G, Yong CS, Woo JS, et al. Development of a novel bi-coated combination capsule containing mosapride and probiotics for irritable bowel syndrome. Pharm Dev Technol. 2015;20(8):949-56. [DOI:10.3109/10837450.2014.954723] [피]

23. Tavakoli M, Hamidi-Esfahani Z, Hejazi MA, Azizi $\mathrm{MH}$, Abbasi S. Characterization of probiotic abilities of Lactobacilli isolated from Iranian Koozeh traditional cheese. Pol J Food Nutr Sci. 2017;67(1):41-8. [DOI:10.1515/pjfns-2016-0003]

24. Rani RP, Anandharaj M, Ravindran AD. Characterization of bile salt hydrolase from Lactobacillus gasseri FR4 and demonstration of its substrate specificity and inhibitory mechanism using molecular docking analysis. Front Microbiol. 2017;8:1004. [DOI:10.3389/fmicb.2017.01004] [PMID] [PMCID] 